\title{
Targeting the p53 Pathway in Ewing Sarcoma
}

\author{
Paul M. Neilsen, ${ }^{1}$ Kathleen I. Pishas, ${ }^{1}$ David F. Callen, ${ }^{1}$ and David M. Thomas ${ }^{2}$ \\ ${ }^{1}$ Sarcoma Research Group, Discipline of Medicine, University of Adelaide and Hanson Institute, Frome Road, \\ Adelaide, SA 5000, Australia \\ ${ }^{2}$ Ian Potter Foundation Centre for Cancer Genomics and Predictive Medicine, Peter MacCallum Cancer Centre, \\ East Melbourne, VIC 3002, Australia
}

Correspondence should be addressed to Paul M. Neilsen, paul.neilsen@health.sa.gov.au

Received 4 July 2010; Accepted 28 October 2010

Academic Editor: Alessandro Gronchi

Copyright (C) 2011 Paul M. Neilsen et al. This is an open access article distributed under the Creative Commons Attribution License, which permits unrestricted use, distribution, and reproduction in any medium, provided the original work is properly cited.

\begin{abstract}
The p53 tumour suppressor plays a pivotal role in the prevention of oncogenic transformation. Cancers frequently evade the potent antitumour surveillance mechanisms of p53 through mutation of the TP53 gene, with approximately $50 \%$ of all human malignancies expressing dysfunctional, mutated p53 proteins. Interestingly, genetic lesions in the TP53 gene are only observed in $10 \%$ of Ewing Sarcomas, with the majority of these sarcomas expressing a functional wild-type p53. In addition, the p53 downstream signaling pathways and DNA-damage cell cycle checkpoints remain functionally intact in these sarcomas. This paper summarizes recent insights into the functional capabilities and regulation of p53 in Ewing Sarcoma, with a particular focus on the cross-talk between p53 and the EWS-FLI1 gene rearrangement frequently associated with this disease. The development of several activators of p53 is discussed, with recent evidence demonstrating the potential of small molecule p53 activators as a promising systemic therapeutic approach for the treatment of Ewing Sarcomas with wild-type p53.
\end{abstract}

\section{Introduction}

The p53 protein, known as the "guardian of the genome" [1] and voted Science magazine's "Molecule of the Year" in 1993, plays a pivotal role in the cellular defense against transformation of cells in the presence of oncogenic or genotoxic stress [2]. This is achieved through the ability of the p53 transcription factor to drive the expression of downstream target genes to evoke cellular responses such as cell cycle arrest, apoptosis, DNA damage repair, and senescence [3]. The development of a malignant neoplasm generally requires attenuation of these p53 responses, and this can occur via mutation of the p53 protein. TP53 is the most frequently altered gene in cancer, with p53 mutations observed in approximately half of all tumours [4]. In contrast, TP53 mutations are infrequent in the Ewing Sarcoma Family of Tumours (ESFTs) with the majority of these sarcomas expressing a functional wild-type p53 [5-14]. Such features are rarely seen in cancers and are suggestive that ESFTs will be sensitive to p53-based targeted therapeutic strategies.

\section{Genomic Integrity of TP53 Is Preserved in Ewing Sarcomas}

Ewing Sarcomas arise in the bones of children and young adolescents and are the most lethal of all bone tumours $[15,16]$. These sarcomas are infrequent neoplasms with international incidence rates in the pediatric population averaging less than two cases per million children. Such low incidence rates have limited the detection of TP53 mutations to relatively small cohorts from independent clinical centres, with these studies reporting TP53 mutation frequencies ranging from $4 \%$ to $20 \%$. A meta-analysis of all primary or metastatic ESFTs involving TP53 point mutations confirmed through direct sequencing reveals that TP53 mutations are observed in approximately $10 \%$ of cases (Table 1 ).

A similar analysis of the available literature suggests that the majority of other sarcoma types are also associated with low frequencies of TP53 mutations, ranging from approximately $6 \%$ in well-differentiated/dedifferentiated liposarcomas to $23 \%$ in osteosarcomas (Table 2). Although malignant fibrous histiocytomas are listed, they are a discredited 
TABLE 1: TP53 Mutations in Ewings Sarcoma confirmed by DNA sequencing.

\begin{tabular}{|c|c|c|c|c|c|}
\hline Sarcoma type & Study & Method & $\begin{array}{l}\text { Exons } \\
\text { sequenced }\end{array}$ & $\begin{array}{l}\text { Mutation } \\
\text { frequency }\end{array}$ & TP53 mutation \\
\hline \multirow{10}{*}{ Ewing Sarcoma } & Kovar et al., 1993 [5] & $\begin{array}{l}\text { PCR-SSCP } \\
\text { Sequencing }\end{array}$ & $4-8$ & $2 / 37$ & C277Y, R273C \\
\hline & Komuro et al., 1993 [6] & $\begin{array}{l}\text { PCR-SSCP } \\
\text { Sequencing }\end{array}$ & $5-9$ & $2 / 14$ & 152(FS), G154V \\
\hline & Hamelin et al., 1994 [7] & $\begin{array}{l}\text { PCR-DGGE } \\
\text { Sequencing }\end{array}$ & $5-8$ & $2 / 12$ & R175H, R248W \\
\hline & $\begin{array}{l}\text { Patiño-García and } \\
\text { Sierrasesúmaga, } 1997 \text { [8] }\end{array}$ & $\begin{array}{l}\text { PCR-DDGE } \\
\text { Sequencing }\end{array}$ & $5-8$ & $1 / 5$ & R273H \\
\hline & Radig et al., 1998 [9] & $\begin{array}{l}\text { IHC } \\
\text { PCR-SSCP } \\
\text { Sequencing }\end{array}$ & $4-8$ & $1 / 24$ & Not Specified \\
\hline & Tsuchiya et al., 2000 [10] & $\begin{array}{l}\text { PCR-SCCP } \\
\text { Sequencing }\end{array}$ & $5-9$ & $1 / 24$ & G154V \\
\hline & $\begin{array}{l}\text { López-Guerrero et al., } \\
2001[11]\end{array}$ & Sequencing & $5-8$ & $3 / 19$ & C135F, A138D, P151R \\
\hline & Park et al., 2001 [13] & $\begin{array}{l}\text { PCR-SSCP } \\
\text { Sequencing }\end{array}$ & $4-9$ & $3 / 35$ & K132M, C135S, Q287V \\
\hline & Huang et al., 2005 [12] & $\begin{array}{l}\text { IHC } \\
\text { p53 } \\
\text { GeneChip } \\
\text { Sequencing }\end{array}$ & - & $8 / 60$ & $\begin{array}{l}\text { W146(STOP), M160L } \\
\text { N239A, G244I, R248Q } \\
\text { R273F, A276S, R342P }\end{array}$ \\
\hline & Schaefer et al., 2008 [14] & Sequencing & $5-8$ & $2 / 17$ & C141Y, R248W \\
\hline \multicolumn{5}{|c|}{ Total TP53 mutations in Ewing Sarcoma } & $25 / 247(10.1 \%)$ \\
\hline
\end{tabular}

DDGE: Denaturing Gradient Gel Electrophoresis; IHC: Immunohistochemistry; PCR-SSCP: Polymerase Chain Reaction Single-Strand Conformational Polymorphism; FS: Frameshift; Mutations in bold indicate p53 "hotspot mutations."

entity and will soon be removed from the World Health Organisation (WHO) sarcoma atlas [17]. Collectively, Ewing Sarcoma was associated with the lowest frequencies of TP53 mutation across all sarcoma types.

The International Agency for Research on Cancer (IARC) has recently released recommendations for the detection of TP53 mutations, and advise direct sequencing of exons 4 to 10 of the TP53 gene [46]. Studies listed in Tables 1 and 2 rarely fulfilled these recommendations. Furthermore, the reported frequencies of TP53 mutations may be marginally underestimated as the majority of these studies sequenced TP53 in patients where an initial screen detected overexpressed p53 protein by immunohistochemistry, rather than performing an unbiased sequencing of all cases. Although mutant p53 is typically stabilized in cancer cells, and overexpression of $\mathrm{p} 53$ protein is predictive of TP53 mutation [47], this indirect approach cannot detect heterozygous truncating mutations of TP53 [46]. Nevertheless, frequencies of TP53 mutation reported by the studies in Tables 1 and 2 are consistent with publicly available sequencing data from the IARC TP53 database in which TP53 point mutations were observed in 373 out of 2145 (17.4\%) tumours from bone or soft tissue origins [46].

The integrity of the p53 pathway in Ewing Sarcomas is further supported by studies suggesting that gross chromosomal alterations involving the TP53 locus on chromosome $17 \mathrm{p}$ are relatively infrequent in ESFT samples [48]. This is in contrast to other bone malignancies, such as osteosarco- mas, where chromosome alterations of the TP53 gene are frequently observed [24, 44, 49, 50].

\section{Genetic Alterations in Regulators of the p53 Pathway}

Typically, cancers that retain wild-type p 53 have been shown to indirectly suppress the p53 regulatory and signaling pathways. One of the most common oncogenic defects observed involves amplification or overexpression of MDM2 [51]. The stability and activity of p53 are constitutively regulated by MDM2 using an auto-regulatory feedback loop which in normal cells prevents inappropriate activation of p53 [52]. MDM2 is an E3 ubiquitin ligase that antagonizes the tumour suppressor function of p53 by silencing the ability of p53 to transactivate target genes or promoting its degradation or nuclear exportation $[53,54]$. However, MDM2 amplification is a rare event in Ewing Sarcomas and is only observed in approximately $2 \%$ of ESFT cases (Table 3 ). In contrast, virtually all well-differentiated and dedifferentiated liposarcomas contain complex marker chromosomes with multiple copies of the MDM2 locus [55].

Cancers can also attenuate $\mathrm{p} 53$ function through deletion of $C D K N 2 A$, the gene encoding p14 ${ }^{\mathrm{ARF}}$ [48]. The p14 $\mathrm{ARF}$ tumour suppressor is a positive regulator of $\mathrm{p} 53$ in response to specific stimuli such as oncogenic stress. The stability of p53 is enhanced by p14 ${ }^{\mathrm{ARF}}$ through its ability to sequester MDM2, thus releasing p53 to activate downstream pathways 
TABLE 2: TP53 Mutations in sarcomas other than ESFTs confirmed by DNA sequencing.

\begin{tabular}{|c|c|c|c|c|c|}
\hline Sarcoma type & Study & Method & $\begin{array}{l}\text { Exons } \\
\text { sequenced }\end{array}$ & $\begin{array}{l}\text { Mutation } \\
\text { frequency }\end{array}$ & TP53 mutation \\
\hline \multicolumn{6}{|l|}{ Liposarcoma } \\
\hline \multirow{6}{*}{$\begin{array}{l}\text { Well-differentiated/de- } \\
\text { differentiated } \\
\text { liposarcoma } \\
\text { (WD/DDLPS) }\end{array}$} & Pilotti et al., 1997 [18] & $\begin{array}{l}\text { IHC } \\
\text { PCR-SSCP } \\
\text { Sequencing }\end{array}$ & $5-9$ & $4 / 13$ & $\begin{array}{l}\text { H179Y, R213(STOP) } \\
\text { R282W, Gg > Gc (SS) }\end{array}$ \\
\hline & $\begin{array}{l}\text { Dei Tos et al., } 1997 \\
{[19]}\end{array}$ & $\begin{array}{l}\text { IHC } \\
\text { PCR-SSCP } \\
\text { Sequencing }\end{array}$ & $5-8$ & $1 / 14$ & S127F \\
\hline & $\begin{array}{l}\text { Schneider-Stock et al., } \\
1998[20]\end{array}$ & $\begin{array}{l}\text { PCR-SSCP } \\
\text { Sequencing }\end{array}$ & $4-8$ & $0 / 8$ & - \\
\hline & $\begin{array}{l}\text { Schneider-Stock et al., } \\
1999[21]\end{array}$ & $\begin{array}{l}\text { IHC } \\
\text { PCR-SSCP } \\
\text { Sequencing }\end{array}$ & $5-8$ & $0 / 13$ & - \\
\hline & $\begin{array}{l}\text { Barretina et al., } 2010 \\
{[22]}\end{array}$ & $\begin{array}{l}\text { Sequencing, } \\
\text { mass } \\
\text { spectrometry- } \\
\text { based } \\
\text { genotyping }\end{array}$ & - & $0 / 50$ & - \\
\hline & & & & $\begin{array}{l}\text { Total TP53 } \\
\text { mutations }\end{array}$ & $5 / 98(5.1 \%)$ \\
\hline \multirow{6}{*}{$\begin{array}{l}\text { Myxoid/Round cell } \\
\text { liposarcoma }\end{array}$} & Pilotti et al., 1997 [18] & $\begin{array}{l}\text { IHC } \\
\text { PCR-SSCP } \\
\text { Sequencing }\end{array}$ & $5-9$ & $1 / 6$ & Del nts 1506-1507 (STOP) \\
\hline & $\begin{array}{l}\text { Schneider-Stock et al., } \\
1998[20]\end{array}$ & $\begin{array}{l}\text { PCR-SSCP } \\
\text { Sequencing }\end{array}$ & $4-8$ & $1 / 12$ & P128S \\
\hline & $\begin{array}{l}\text { Schneider-Stock et al., } \\
1999[21]\end{array}$ & $\begin{array}{l}\text { IHC } \\
\text { PCR-SSCP } \\
\text { Sequencing }\end{array}$ & $5-8$ & $3 / 19$ & H214L, P250T, G245S \\
\hline & Oda et al., 2005 [23] & $\begin{array}{l}\text { IHC } \\
\text { PCR-SSCP } \\
\text { Sequencing }\end{array}$ & $5-9$ & $5 / 77$ & $\begin{array}{l}\text { Q167(STOP), H214Y } \\
\text { V225A, C238Y, C242Y }\end{array}$ \\
\hline & $\begin{array}{l}\text { Barretina et al., } 2010 \\
{[22]}\end{array}$ & $\begin{array}{l}\text { Sequencing, mass } \\
\text { spectrometry- } \\
\text { based } \\
\text { genotyping }\end{array}$ & - & $0 / 21$ & - \\
\hline & & & & $\begin{array}{l}\text { Total TP53 } \\
\text { Mutations }\end{array}$ & $10 / 135(7.4 \%)$ \\
\hline \multirow{4}{*}{$\begin{array}{l}\text { Pleomorphic } \\
\text { liposarcoma }\end{array}$} & $\begin{array}{l}\text { Schneider-Stock et al., } \\
1998[20]\end{array}$ & $\begin{array}{l}\text { PCR-SSCP } \\
\text { Sequencing }\end{array}$ & $4-8$ & $3 / 6$ & $\begin{array}{l}\text { R248Q, E271(STOP) } \\
\text { R273C }\end{array}$ \\
\hline & $\begin{array}{l}\text { Schneider-Stock et al., } \\
1999[21]\end{array}$ & $\begin{array}{l}\text { IHC } \\
\text { PCR-SSCP } \\
\text { Sequencing }\end{array}$ & $5-8$ & $2 / 9$ & R248Q, R273C \\
\hline & $\begin{array}{l}\text { Barretina et al., } 2010 \\
{[22]}\end{array}$ & $\begin{array}{l}\text { Mass } \\
\text { spectrometry- } \\
\text { based } \\
\text { genotyping }\end{array}$ & - & $4 / 24$ & $\begin{array}{l}\text { C135F, T155I } \\
\text { C > TT (SS), C > CT (SS) }\end{array}$ \\
\hline & & & & $\begin{array}{l}\text { Total TP53 } \\
\text { mutations }\end{array}$ & $9 / 39(23.1 \%)$ \\
\hline \multirow{4}{*}{$\begin{array}{l}\text { Undefined } \\
\text { liposarcomas }\end{array}$} & $\begin{array}{l}\text { Toguchida et al., } 1992 \\
{[24]}\end{array}$ & $\begin{array}{l}\text { PCR-SSCP } \\
\text { Sequencing }\end{array}$ & $2-11$ & $1 / 4$ & AGgt > AGtt (SS) \\
\hline & Leach et al., 1993 [38] & $\begin{array}{l}\text { IHC } \\
\text { Sequencing }\end{array}$ & $5-8$ & $3 / 13$ & $\begin{array}{l}\text { Q144(STOP), N239S } \\
\text { GGT > GAT }(\mathrm{SS})\end{array}$ \\
\hline & Latres et al., 1994 [25] & $\begin{array}{l}\text { PCR-SSCP } \\
\text { Sequencing }\end{array}$ & $2-9$ & $5 / 25$ & $\begin{array}{l}\text { H168R, H193Y, M246V } \\
\text { R248W, 344(STOP) }\end{array}$ \\
\hline & $\begin{array}{l}\text { Castresana et al., } 1995 \\
{[26]}\end{array}$ & $\begin{array}{l}\text { PCR-SSCP } \\
\text { Sequencing }\end{array}$ & $5-8$ & $1 / 4$ & V216A \\
\hline
\end{tabular}


TABle 2: Continued.

\begin{tabular}{|c|c|c|c|c|c|}
\hline Sarcoma type & Study & Method & $\begin{array}{l}\text { Exons } \\
\text { sequenced }\end{array}$ & $\begin{array}{l}\text { Mutation } \\
\text { frequency }\end{array}$ & TP53 mutation \\
\hline & Nawa et al., 1999 [27] & $\begin{array}{l}\text { PCR-SSCP } \\
\text { Sequencing }\end{array}$ & $5-8$ & $1 / 9$ & T253A \\
\hline & Das et al., 2007 [28] & $\begin{array}{l}\text { IHC } \\
\text { Sequencing }\end{array}$ & $2-11$ & $1 / 3$ & 377(FS) \\
\hline & & & & $\begin{array}{l}\text { Total TP53 } \\
\text { mutations }\end{array}$ & $12 / 58(20.7 \%)$ \\
\hline & Total TP53 mutat & ions in liposarcoma & & & $36 / 330(10.9 \%)$ \\
\hline \multirow{9}{*}{ Rhabdomyosarcoma } & Felix et al., 1992 [29] & $\begin{array}{l}\text { PCR-SSCP } \\
\text { Sequencing }\end{array}$ & $4-8$ & $1 / 6$ & $\mathrm{R} 213 \mathrm{P}$ \\
\hline & $\begin{array}{l}\text { Toguchida et al., } 1992 \\
{[24]}\end{array}$ & $\begin{array}{l}\text { PCR-SSCP } \\
\text { Sequencing }\end{array}$ & $2-11$ & $0 / 4$ & - \\
\hline & Latres et al., 1994 [25] & $\begin{array}{l}\text { PCR-SSCP } \\
\text { Sequencing }\end{array}$ & $2-9$ & $0 / 2$ & - \\
\hline & $\begin{array}{l}\text { Castresana et al., } 1995 \\
{[26]}\end{array}$ & $\begin{array}{l}\text { PCR-SSCP } \\
\text { Sequencing }\end{array}$ & $5-8$ & $1 / 1$ & V218L \\
\hline & $\begin{array}{l}\text { Kusafuka et al., } 1997 \\
{[30]}\end{array}$ & $\begin{array}{l}\text { PCR-SSCP } \\
\text { Sequencing }\end{array}$ & $5-8$ & $1 / 10$ & R273H \\
\hline & Nawa et al., 1999 [27] & $\begin{array}{l}\text { PCR-SSCP } \\
\text { Sequencing }\end{array}$ & $5-8$ & $0 / 2$ & - \\
\hline & Taylor et al., 2000 [31] & $\begin{array}{l}\text { PCR-SSCP } \\
\text { Sequencing }\end{array}$ & $5-9$ & $1 / 20$ & Del nt 1004-1017 \\
\hline & $\begin{array}{l}\text { Takahashi et al., } 2004 \\
\text { [32] }\end{array}$ & $\begin{array}{l}\text { PCR-SSCP } \\
\text { Sequencing }\end{array}$ & $5-9$ & $9 / 45$ & $\begin{array}{l}\text { E204G, R209T, P223R } \\
\text { M243T, G245C, N247D, } \\
\text { R249G, C291Q, P295H }\end{array}$ \\
\hline & Das et al., 2007 [28] & $\begin{array}{l}\text { IHC } \\
\text { Sequencing }\end{array}$ & $2-11$ & $1 / 4$ & D393N \\
\hline \multicolumn{5}{|c|}{ Total TP53 mutations in rhabdomyosarcomas } & $14 / 94(14.9 \%)$ \\
\hline \multirow{10}{*}{ Synovial Sarcoma } & $\begin{array}{l}\text { Toguchida et al., } 1992 \\
{[24]}\end{array}$ & $\begin{array}{l}\text { PCR-SSCP } \\
\text { Sequencing }\end{array}$ & $2-11$ & $0 / 5$ & - \\
\hline & Latres et al., 1994 [25] & $\begin{array}{l}\text { PCR-SSCP } \\
\text { Sequencing }\end{array}$ & $2-9$ & $0 / 8$ & - \\
\hline & $\begin{array}{l}\text { Schneider-Stock et al., } \\
1997 \text { [33] }\end{array}$ & $\begin{array}{l}\text { IHC } \\
\text { PCR-SSCP } \\
\text { Sequencing }\end{array}$ & $5-8$ & $0 / 2$ & - \\
\hline & $\begin{array}{l}\text { Dei Tos et al., } 1999 \\
\text { [34] }\end{array}$ & $\begin{array}{l}\text { PCR-SSCP } \\
\text { Sequencing }\end{array}$ & - & $4 / 20$ & Not Specified \\
\hline & Nawa et al., 1999 [27] & $\begin{array}{l}\text { PCR-SSCP } \\
\text { Sequencing }\end{array}$ & $5-8$ & $1 / 7$ & L194F \\
\hline & $\begin{array}{l}\text { Schneider-Stock et al., } \\
1999 \text { [35] }\end{array}$ & $\begin{array}{l}\text { IHC } \\
\text { PCR-SSCP } \\
\text { Sequencing }\end{array}$ & $5-8$ & $2 / 19$ & P128L, R248W \\
\hline & Oda et al., 2000 [36] & $\begin{array}{l}\text { IHC } \\
\text { PCR-SSCP } \\
\text { Sequencing }\end{array}$ & $5-9$ & $9 / 49$ & $\begin{array}{l}\text { C141Y, A159T,V173M } \\
\text { I195F, R196Q, G199R } \\
\text { R213(STOP), N235D } \\
\text { C238Y }\end{array}$ \\
\hline & Das et al., 2007 [28] & $\begin{array}{l}\text { IHC } \\
\text { Sequencing }\end{array}$ & $2-11$ & $5 / 7$ & $\begin{array}{l}\text { 9(STOP), A63P, S96C, } \\
\text { P250T, P250T }\end{array}$ \\
\hline & $\begin{array}{l}\text { Barretina et al., } 2010 \\
{[22]}\end{array}$ & $\begin{array}{l}\text { Sequencing, mass } \\
\text { spectrometry- } \\
\text { based } \\
\text { genotyping }\end{array}$ & - & $0 / 23$ & - \\
\hline & \multicolumn{3}{|c|}{ Total TP53 mutations in Synovial Sarcomas } & & $21 / 140(15.0 \%)$ \\
\hline
\end{tabular}


Table 2: Continued.

\begin{tabular}{|c|c|c|c|c|c|}
\hline Sarcoma type & Study & Method & $\begin{array}{l}\text { Exons } \\
\text { sequenced }\end{array}$ & $\begin{array}{l}\text { Mutation } \\
\text { frequency }\end{array}$ & TP53 mutation \\
\hline \multirow{8}{*}{$\begin{array}{l}\text { Malignant Fibrous } \\
\text { Histiocytoma }\end{array}$} & $\begin{array}{l}\text { Toguchida et al., } 1992 \\
\text { [24] }\end{array}$ & $\begin{array}{l}\text { PCR-SSCP } \\
\text { Sequencing }\end{array}$ & $2-11$ & $2 / 13$ & R196(STOP), R273H \\
\hline & $\begin{array}{l}\text { Andreassen et al., } \\
1993 \text { [37] }\end{array}$ & $\begin{array}{l}\text { CDGE } \\
\text { Sequencing }\end{array}$ & $5,7,8$ & $3 / 12$ & V143M, Y163C, G244D \\
\hline & Leach et al., 1993 [38] & $\begin{array}{l}\text { IHC } \\
\text { Sequencing }\end{array}$ & $5-8$ & $1 / 11$ & $\mathrm{R} 158 \mathrm{H}$ \\
\hline & Latres et al., 1994[25] & $\begin{array}{l}\text { PCR-SSCP } \\
\text { Sequencing }\end{array}$ & $2-9$ & $0 / 9$ & - \\
\hline & $\begin{array}{l}\text { Castresana et al., } 1995 \\
{[26]}\end{array}$ & $\begin{array}{l}\text { PCR-SSCP } \\
\text { Sequencing }\end{array}$ & $5-8$ & $3 / 12$ & Not Specified \\
\hline & $\begin{array}{l}\text { Schneider-Stock et al., } \\
1997 \text { [33] }\end{array}$ & $\begin{array}{l}\text { IHC } \\
\text { PCR-SSCP } \\
\text { Sequencing }\end{array}$ & $5-8$ & $2 / 15$ & Y220C, C277(STOP) \\
\hline & Nawa et al., 1999[27] & $\begin{array}{l}\text { PCR-SSCP } \\
\text { Sequencing }\end{array}$ & $5-8$ & $5 / 15$ & $\begin{array}{l}\text { Y126F, R175H } \\
\text { R213(STOP), S241T } \\
\text { R248Q }\end{array}$ \\
\hline & Das et al., 2007 [28] & $\begin{array}{l}\text { IHC } \\
\text { Sequencing }\end{array}$ & $2-11$ & $2 / 11$ & P77Q, 213(FS) \\
\hline \multicolumn{5}{|c|}{ Total TP53 mutations in malignant fibrous histiocytoma } & $18 / 98(18.4 \%)$ \\
\hline \multirow{13}{*}{ Leiomyosarcoma } & $\begin{array}{l}\text { Andreassen et al., } \\
1993 \text { [37] }\end{array}$ & $\begin{array}{l}\text { CDGE } \\
\text { Sequencing }\end{array}$ & $5,7,8$ & $2 / 6$ & K132M, R248W \\
\hline & Latres et al., 1994[25] & $\begin{array}{l}\text { PCR-SSCP } \\
\text { Sequencing }\end{array}$ & $2-9$ & $5 / 13$ & $\begin{array}{l}\text { Y163C, Y163C, H214R, } \\
\text { G266E, } \\
\text { ATgg > ATag (SS Intron 5) }\end{array}$ \\
\hline & $\begin{array}{l}\text { Patterson et al., } 1994 \\
\text { [39] }\end{array}$ & $\begin{array}{l}\text { PCR-SSCP } \\
\text { Sequencing }\end{array}$ & $4-9$ & $6 / 29$ & $\begin{array}{l}\text { P151H, P152L, R158H } \\
\text { V216M, C238F, V272M }\end{array}$ \\
\hline & $\begin{array}{l}\text { Castresana et al., } 1995 \\
\text { [26] }\end{array}$ & $\begin{array}{l}\text { PCR-SSCP } \\
\text { Sequencing }\end{array}$ & $5-8$ & $1 / 1$ & Not Specified \\
\hline & Miller et al., 1996 [40] & $\begin{array}{l}\text { PCR-SSCP } \\
\text { Sequencing }\end{array}$ & $2-11$ & $1 / 8$ & Q165(STOP) \\
\hline & Hall et al., 1997 [41] & $\begin{array}{l}\text { IHC } \\
\text { PCR-SSCP } \\
\text { Sequencing }\end{array}$ & $5-8$ & $3 / 21$ & $\begin{array}{l}\text { K163E, T211I } \\
\text { A nt Del codon } 246\end{array}$ \\
\hline & $\begin{array}{l}\text { Schneider-Stock et al., } \\
1997 \text { [33] }\end{array}$ & $\begin{array}{l}\text { IHC } \\
\text { PCR-SSCP } \\
\text { Sequencing }\end{array}$ & $5-8$ & $0 / 7$ & - \\
\hline & Nawa et al., 1999[27] & $\begin{array}{l}\text { PCR-SSCP } \\
\text { Sequencing }\end{array}$ & $5-8$ & $0 / 3$ & - \\
\hline & Zhai et al., 1999 [42] & $\begin{array}{l}\text { IHC } \\
\text { Sequencing }\end{array}$ & $5-8$ & $9 / 21$ & $\begin{array}{l}\text { V173M, Y205C, S215R, } \\
\text { R248Q, R249W, R273H, } \\
\text { A276D, E285D, S303I }\end{array}$ \\
\hline & $\begin{array}{l}\text { Miyajima et al., } 2001 \\
{[43]}\end{array}$ & $\begin{array}{l}\text { IHC } \\
\text { PCR-SSCP } \\
\text { Sequencing }\end{array}$ & $5-9$ & $8 / 13$ & $\begin{array}{l}\text { A161T, D184N, T220C } \\
\text { T220C, C238S, C238C } \\
\text { R273H, G279V }\end{array}$ \\
\hline & Das et al., 2007 [28] & $\begin{array}{l}\text { IHC } \\
\text { Sequencing }\end{array}$ & $2-11$ & $0 / 5$ & - \\
\hline & $\begin{array}{l}\text { Barretina et al., } 2010 \\
{[22]}\end{array}$ & $\begin{array}{l}\text { Sequencing, mass } \\
\text { spectrometry- } \\
\text { based } \\
\text { genotyping }\end{array}$ & - & $0 / 27$ & - \\
\hline & \multicolumn{3}{|c|}{ Total TP53 mutations in leiomyosarcomas } & & $35 / 154(22.7 \%)$ \\
\hline
\end{tabular}


Table 2: Continued.

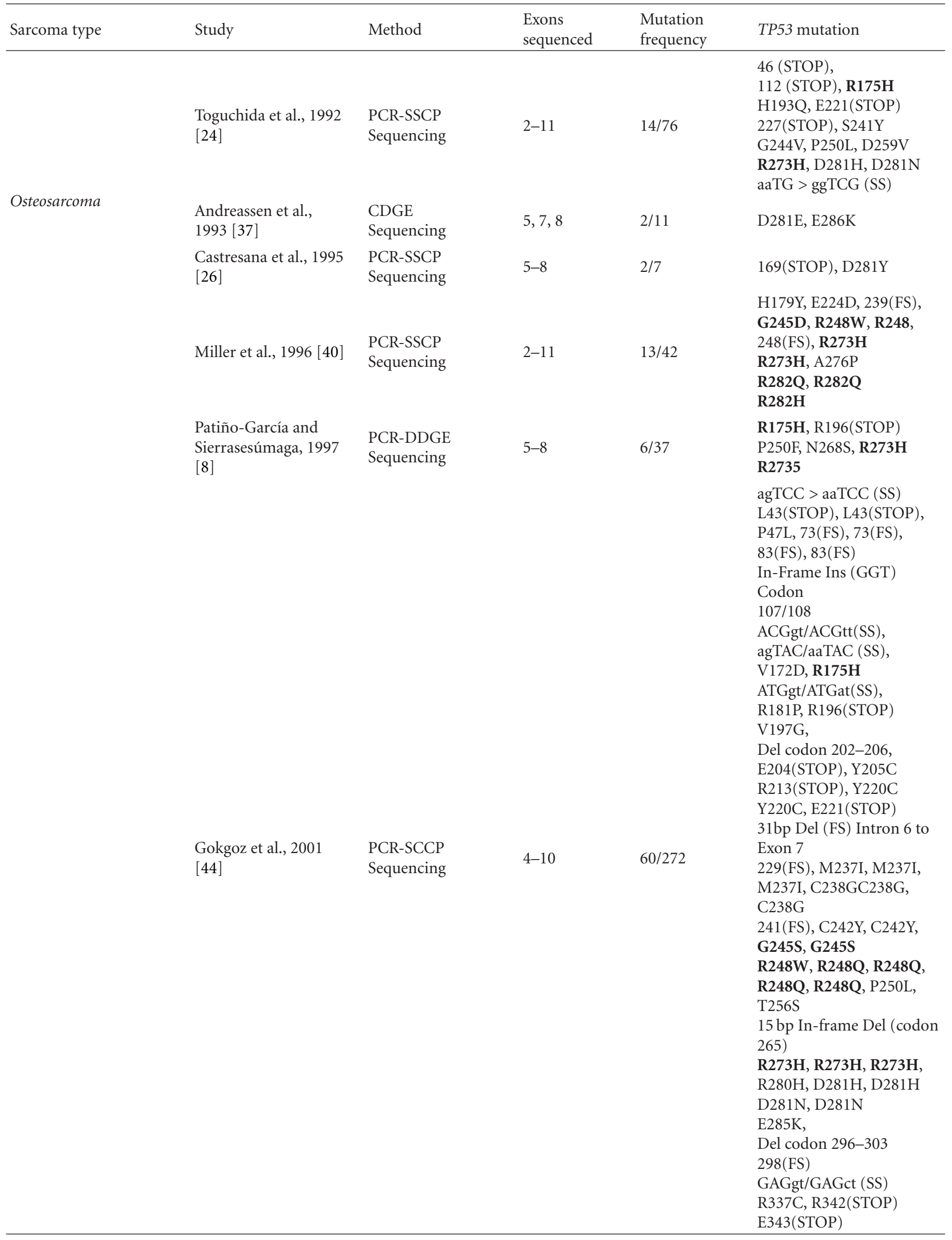


TABle 2: Continued.

\begin{tabular}{|c|c|c|c|c|c|}
\hline Sarcoma type & Study & Method & $\begin{array}{l}\text { Exons } \\
\text { sequenced }\end{array}$ & $\begin{array}{l}\text { Mutation } \\
\text { frequency }\end{array}$ & TP53 mutation \\
\hline & $\begin{array}{l}\text { Overholtzer et al., } \\
2003 \text { [45] }\end{array}$ & $\begin{array}{l}\text { PCR-SCCP } \\
\text { PCR-LDR }\end{array}$ & $5-8$ & $12 / 32$ & $\begin{array}{l}\text { V173G, V173M, R175H, } \\
\text { Del codon 175, } \\
\text { Y220C, E224D, V272M, } \\
\text { R273H, R273C, D281H } \\
\text { FS (Exon 6), } \\
\text { FS (Del 17nt) Exon } 5\end{array}$ \\
\hline \multicolumn{5}{|c|}{ Total TP53 mutations in osteosarcomas } & $109 / 477(22.9 \%)$ \\
\hline
\end{tabular}

CDGE: Constant Denaturant Gel Electrophoresis; DDGE: Denaturing Gradient Gel Electrophoresis; IHC: Immunohistochemistry; PCR-SSCP: Polymerase Chain Reaction Single-Strand Conformational Polymorphism; PCR-LDR: Polymerase Chain Reaction Ligase-Detection Reaction; FS: Frame shift; Del: Deletion; Ins: Insertion; SS: Splice Site. Mutations in bold indicate p53 "hotspot mutations". Recurrences with TP53 mutations have been omitted in studies that reported both the primary tumour and recurrence with the same mutation.

of growth suppression or apoptosis [56, 57]. A summary of the available literature related to CDKN2A chromosomal alterations in ESFT cases revealed that either homozygous or hemizygous deletion of the CDKN2A locus are also relatively infrequent events, occurring in less than $20 \%$ of all cases (Table 3). CDKN2A alterations and TP53 mutations are mutually exclusive events in the majority of ESFT cases, suggesting that either genetic insult is sufficient to inactivate the p53 pathway in these cancers $[11,48]$.

MDM4 is another key negative regulator of the p53 pathway [61-63]. This oncoprotein is closely related to MDM2 with significant homology between their DNA binding domains; however, MDM4 has a more specific role in the negative regulation of p53 transcriptional activity. Amplification of the MDM4 gene has also been reported in several tumour types, with MDM4 amplification observed in 65\% of retinoblastomas [64]. MDM2 and MDM4 amplification are rarely observed within the same tumour, suggesting that either event is sufficient to inactivate the p53 pathway. MDM4 amplification is a possible mechanism for functional inactivation of the p53 pathway in Ewing Sarcoma given the infrequent occurrences of MDM2 amplification, CDKN2A deletion, or TP53 mutation in these cancers. Unfortunately, previous cytogenetic studies are restricted to investigating allelic imbalance of the TP53, MDM2, and CDKN2A loci in ESFT patient material, hence the frequency of MDM4 amplifications in Ewing Sarcoma is currently unknown.

The small proportion of ESFT cases with either MDM2 amplification or p14 ${ }^{\mathrm{ARF}}$ deletion cannot collectively account for the ability of Ewing Sarcomas to develop in a cellular context with wild-type p53. Further investigations of Ewing Sarcoma are warranted to conclusively determine if the mechanisms that attenuate the p53 response during sarcomagenesis occur at the genetic or posttranslational level. The presence of an EWS-ETS translocation event is a universal feature of Ewing Sarcoma and represents another possible genetic alteration responsible for the regulation of p53 in ESFT. Recent insights into the functional characterization of the resulting oncogenic gene product suggest a potential role of this ubiquitous translocation event in silencing p53 activity in ESFTs (see later discussion).

\section{The p53 Signaling Pathways Are Functionally Intact in Ewing Sarcoma}

Abrogation of the p53 pathway through TP53 mutation is typically associated with enhanced tumour invasive and metastatic capabilities, and poorer patient survival rates [46, 65]. Ewing Sarcoma is an aggressive malignancy with the lowest patient survival rates of all primary musculoskeletal tumours, traits rarely possessed by cancers that retain wildtype p53. Despite observations that TP53 alterations and MDM2 amplifications are infrequent events in primary Ewing Sarcomas, it has been speculated that the downstream signaling pathways of p53 may be inactive in these sarcomas. In order to test the functional intactness of these p53 signaling pathways in Ewing Sarcoma, Heinrich Kovar and colleagues investigated the response of several ESFT cell lines with varying p53 status to ectopic p53 expression [66]. A prolonged apoptotic or growth arrest phenotype was observed upon ectopic expression of wild-type p53 in the cell lines. The sensitivity of Ewing Sarcoma cell lines to X-irradiation was also dependent on the expression of an endogenous wild-type p53. These findings confirm the intactness of the p53 signaling pathways in Ewing Sarcoma.

The frequent normal functioning of the p 53 signaling pathway in ESFTs is also demonstrated by the observation that almost all Ewing Sarcoma cell lines have acquired either TP53 mutations or CDKN2A deletions, suggesting selective pressure for these genetic alterations to permit in vitro growth [67]. Similar observations have been made in the clinic, with p53 mutation and CDKN2A deletion defining a lethal subset of ESFTs associated with poor response to chemotherapy [12]. In conclusion, the in vitro and in vivo evidence suggests the p53 signaling pathways are intact in a significant proportion of Ewing Sarcomas.

\section{The Prognostic Significance of TP53 Alterations}

ESFT patients with point mutation of TP53 are associated with a poor prognosis $[12,68,69]$. Logically, one would expect a genetic event that confers a growth advantage to be highly represented across a tumour type through selective pressure. This is not the case in Ewing Sarcoma, as TP53 
TABLE 3: MDM2 amplification or CDKN2A deletion in Ewing Sarcomas.

\begin{tabular}{lccc}
\hline Study & MDM2 amplification & Study & CDKN2A deletion \\
\hline Kovar et al., 1993 [5] & $0 / 17$ & Kovar et al., 1997 [5] & $7 / 27^{\#}$ \\
Ladanyi et al., 1995 [58] & $3 / 30$ & Wei et al., 2000 [59] & $7 / 39^{\#}$ \\
Tsuchiya et al., 2000 [10] & $0 / 24$ & López-Guerrero et al., 2001 [11] & $4 / 19^{\#}$ \\
Park et al., 2001 [13] & $0 / 35$ & Brownhill et al., 2007 [60] & $6 / 42^{*}$ \\
López-Guerrero et al., 2001 [11] & $0 / 19$ & Tópez-Guerrero et al., 2010 [48] & $34 / 169^{*}$ \\
\hline Total MDM Amplifications & $3 / 125(2.4 \%)$ & & $58 / 296(19.6 \%)$ \\
\hline "Homozygous deletion of CDKN2A & &
\end{tabular}

mutations rarely occur, yet define a high-risk population of patients.

Huang and colleagues have provided the most compelling evidence thus far for TP53 mutation as an independent prognostic marker using a combined immunohistochemistry, Genechip and sequencing approach to detect TP53 mutations in 60 ESFTs [12]. TP53 mutations were identified in 8 of these 60 cases (13.3\%), and all eight patients expressing mutant p53 ESFTs died within 21 months of diagnosis with a mean survival of 11 months, as compared to a mean survival of 99 months for patients with wild-type p53 ESFTs. Multivariate analysis identified TP53 mutation as the strongest independent prognostic factor [12]. This is the largest prognostic study to date that involves DNA sequencing of TP53 in ESFT patient material.

The prognostic involvement of p53 mutation in Ewing Sarcoma was recently challenged by findings from a retrospective study involving 308 ESFT cases collected from 1971 to 2007 [48]. Although overexpression of p53 protein was detected in $25 \%$ of these cases, this study restricted the classification of "p53 mutation" to these cases which did not express p $21^{\text {Waf1/Cip1 }}$, the strongest canonical p53 target. Subsequently, 15\% of ESFT cases where deemed to express mutant p53 upon application of these criteria. This study showed that "mutant p53" expression was more frequent in disseminated disease than in primary localized tumors, indicating a role in the progression and metastasis of Ewing Sarcoma. However, there was no association between "mutant p53" expression and patient survival. The conclusions from this study are limited by the absence of actual TP53 sequencing of ESFT samples to confirm the presence of TP53 mutations. These observations need to be attested by further investigation into the prognostic value of TP53 mutations using unbiased direct sequencing approaches.

Gross chromosome rearrangements involving TP53 have been recently reported to influence the prognosis of Ewing Sarcoma $[48,70]$. Alteration of $17 \mathrm{p}$ (the chromosomal arm containing the TP53 locus) was observed in $16.7 \%$ of ESFT samples and was associated with significantly poorer survival rates [70]. Lopez-Guerrero and colleagues recently showed that alteration the TP53 locus alone was a prognostic marker for poor patient outcome [48]. Gross alteration of TP53 gene was detected in 32 of 191 (17\%) ESFT cases. Interestingly, the strongest prognostic information from these studies was observed upon loss of heterozygosity (LOH) of $16 \mathrm{q}$, which occurred in $20.8 \%$ of cases and was the most significant indicator of poor outcome [70]. A recent study that used a combined comparative genomic hybridization (CGH) and expression microarray analysis identified the ANKRD11 locus at 16q24.3 as one of the most frequently deleted and down-regulated genes in Ewing Sarcoma [71]. It is noteworthy that ANKRD11 was recently reported as a p53 coactivator [72], suggesting that the loss of p53 activators may contribute towards the ability of Ewing Sarcomas to develop and progress in the presence of a wild-type p53.

Studies to date are consistent with the presence of TP53 point mutations in defining a high-risk population of ESFT patients. However, more detailed studies are warranted to conclusively evaluate the prognostic potential of TP53 point mutation. Collectively, these findings indicate that the prognostic potential of mutant p53 will be fully realized through the application of definitive approaches to detect TP53 mutations.

\section{Oncogenic EWS-ETS Translocations}

ESFTs are cytogenetically diagnosed through specific genetic rearrangement involving the EWS gene (official symbol EWSR1) and a member of the ETS transcription factor gene family. This chimeric fusion protein is present in over $90 \%$ of ESFTs $[73,74]$ and is widely considered to be causative of this malignancy. The EWS-FLI1 translocation, $\mathrm{t}(11 ; 22)(\mathrm{q} 24 ; 12)$, is a chromosomal aberration specific to ESFTs and accounts for $85 \%$ of translocation events in Ewing Sarcoma. This reciprocal translocation generates fusion of the $5^{\prime}$ segment of EWS on chromosome 22 with the $3^{\prime}$ segment of FLI-1 on chromosome 11. Antisense DNA studies have confirmed that continuous EWS-FLI1 expression is required for the in vitro proliferation and in vivo tumorigenic capacity of Ewing Sarcoma cells [75-78]. The second most common EWS translocation described involves an in-frame fusion of the EWS and $E R G$ genes as a result of the $\mathrm{t}(21 ; 22)(\mathrm{q} 22 ; \mathrm{q} 12)$ translocation, accounting for 5\% of translocations in Ewing Sarcoma [74].

\section{Suppression of p53 Activity by EWS-FLI1}

Attenuation of the p53 tumour surveillance mechanisms during the development and progression of Ewing Sarcomas may be explained through the ability of the EWS-FLI1 oncoprotein to silence p53 activity. Two independent studies have shown that silencing of EWS-FLI1 expression in Ewing Sarcoma cell lines increases p53 activity $[79,80]$, suggesting 
that the EWS-FLI1 fusion protein plays a role in the constitutive silencing of p53 tumour suppressor activity. It appears that EWS-FLI1 can achieve this through either an indirect mechanism, involving the Notch signaling pathway [79], or through the formation of a protein complex involving EWSFLI1 and p53 [80]. This study suggests that EWS-FLI1 attenuates p53 activity through physically sequestration facilitated by the EWS region of the fusion protein [80]. However, it is unclear whether interaction between p53 and EWSFLI1 occurs directly or is mediated through other oncogenic binding partners. It is of great interest that the amino region of EWS enables the recruitment of p53 to EWS-FLI1, as this p53-binding region is present in almost all Ewing Sarcoma gene translocation events and numerous other translocationbased cancers (Table 4). Such observations suggest that these malignancies share a common mechanism involving EWS that may potentially involve the functional inactivation of p53.

The ability of EWS-FLI1 to suppress p53 activity in Ewing Sarcoma is reminiscent of the functional role of the oncogenic translocation product in synovial sarcomas. The presence of the SS18-SSX fusion protein as a result of the $\mathrm{t}(\mathrm{X}: 18)(\mathrm{p} 11.2 ; \mathrm{q} 11.2)$ translocation is a universal feature of synovial sarcoma [94]. These sarcomas abrogate p53 protein levels through its enhanced proteasomal degradation facilitated by SS18-SSX [95]. Reminiscent of Ewing Sarcoma, TP53 mutations are rare events in synovial sarcomas (Table 1), suggesting that these cancers rely on the ability of the SS18-SSX fusion protein to abrogate the p53 response, facilitating oncogenic transformation in the presence of a functional, wild-type p53.

\section{EWS-FLI1 Expression Stimulates the p53 Pathway in Normal Cells, Fibroblasts, or Nonmesenchymal Cells}

The development of an animal model to investigate the oncogenic properties of EWS-FLI1 has been limited by the toxic effects associated with the expression of this potent fusion protein in primary cells [96]. Due to the absence of an adequate transgenic animal model for Ewing Sarcoma, experimental approaches have been restricted to forced expression of EWS-FLI1 in various cell lines. Introduction of EWS-FLI1 into primary human fibroblasts resulted in a growth arrest through stimulation of the p53 pathway [96]. Subsequent specific inhibition of p53 activity in these fibroblasts rescued the growth arrest phenotype, allowing EWS-FLI1 to promote anchorage-independent growth of these fibroblasts. Similar effects have been observed in mouse embryonic fibroblasts (MEFs) in which expression of EWSFLI1 induced the p53-dependent growth arrest or apoptosis [97]. This apoptotic or growth arrest response was considered to be p53-dependent, as MEFs null for p53, p19ARF, or p16 were unaffected in response to EWS-FLI1 expression. Normal cells retaliate this aberrant oncogene expression by mounting a p53-based defense mechanism resulting in cellular apoptosis or senescence [98, 99]. Consideration of the responses elicited by EWS-FLI1 in normal cells therefore suggests this fusion protein in functioning as a potent oncogene and is reminiscent of the responses associated with elevated levels of the MYC or RAS oncogenes.

The cellular response to ectopically expressed EWS-FLI1 varies in primary cells of different origin. Ewing Sarcomas are derived from mesenchymal progenitor cells (MPCs) [100], and forced expression of EWS-FLI1 in MPCs was shown to be stably maintained without growth arrest or apoptosis whilst inducing an gene expression profile similar to that of a Ewing Sarcoma, all in the presence of a functional, wild-type p53 [101-103]. Such findings raise questions surrounding the ability of primary MPCs to tolerate forced EWS-FLI1 expression without engaging a p53-dependent response to the oncogenic stress. Nevertheless, the mechanisms used by MPCs to abide the expression of EWS-FLI1 in the presence of wild-type p53, whilst such expression in other primary cell lines triggers a p53 response, remain largely unknown.

Attempts have been made to investigate the function of EWS-FLI1 in a transgenic mouse model. While the conditional expression of EWS-FLI1 in mouse MPCs did not induce the formation of Ewing Sarcomas, this expression of EWS-FLI1 in mice was able to influence sarcoma development in the absence of p53 [104]. Conditional TP53 deletion in mouse MPCs led to the development osteosarcomas with a median tumour onset time of 50 weeks from birth. However, when EWS-FLI1 was conditionally expressed in these p53null MPCs, an accelerated tumour growth from a median time of 50 to 21 weeks was observed, with the histological phenotype of these malignancies shifting towards a more poorly differentiated sarcoma [104]. These data provide in vivo evidence to further support the cross-talk between p53 and EWS-FLI1 which is essential in primary MPCs for the development of Ewing Sarcomas.

\section{IGF1R and p53 Signaling Pathways}

The activity of insulin-like growth factor 1 receptor (IGF1R) is essential for tumour development and progression through the signaling of antiapoptotic and prosurvival pathways [105-107]. IGF1R is also often overexpressed at the cell surface of malignant cells and thus has emerged as an attractive therapeutic target in cancer. A role of the IGF signaling pathway in the development of Ewing Sarcoma is evident through the finding that silencing of the EWSFLI1 oncoprotein showed upregulation and activation of IGFBP genes [108]. Ewing Sarcoma cell lines are highly sensitive to IGF1R inhibitors, especially in combination with conventional chemotherapy $[16,109]$. The IGF1R antagonist, AMG 479, has shown promising results in the treatment of ESFTs in a phase I clinical trial, indicating that Ewing Sarcomas may be particularly sensitive to intervention of the IGF1R signaling pathway $[110,111]$. However, these studies raise vital questions as to why striking responses are seen in some, but not all, patients treated with these agents.

IGF1R and p53 drive distinctly opposing biological outcomes, with a significant level of molecular cross-talk occurring between these two signaling pathways. Initial studies suggested that p53 retorts the antiapoptotic signaling of IGF1R through repression of IGF1R expression [112]. Further antagonism of IGF1R activity by p53 was 
TABLE 4: Involvement of the EWS gene in translocation-based malignancies.

\begin{tabular}{|c|c|c|c|}
\hline Tumour type & Fusion gene & Translocation & Reference \\
\hline \multirow{5}{*}{ Ewing Sarcoma } & EWS-FLI1 & $\mathrm{t}(11 ; 22)(\mathrm{q} 24 ; \mathrm{q} 12)$ & {$[73]$} \\
\hline & $E W S-E R G$ & $\mathrm{t}(21 ; 22)(\mathrm{q} 22 ; \mathrm{q} 12)$ & {$[81]$} \\
\hline & EWS-ETV1 & $\mathrm{t}(7 ; 22)(\mathrm{p} 22 ; \mathrm{q} 12)$ & {$[82]$} \\
\hline & EWS-ETV4 & $\mathrm{t}(17 ; 22)(\mathrm{q} 12 ; \mathrm{q} 12)$ & {$[83]$} \\
\hline & EWS-FEV & $\mathrm{t}(2 ; 22)(\mathrm{q} 33 ; \mathrm{q} 12)$ & {$[84]$} \\
\hline Acute Leukemia & EWS-CIZ1 & $\mathrm{t}(12 ; 22)(\mathrm{p} 13 ; \mathrm{q} 12)$ & {$[85]$} \\
\hline Angiomatoid Fibrous & EWS-ATF1 & $\mathrm{t}(12 ; 22)(\mathrm{q} 13 ; \mathrm{q} 12)$ & {$[86]$} \\
\hline Histiocytoma & EWS-CREB1 & $\mathrm{t}(2 ; 22)(\mathrm{q} 33 ; \mathrm{q} 12)$ & {$[87]$} \\
\hline \multirow{2}{*}{ Clear-cell Sarcoma } & EWS-ATF1 & $\mathrm{t}(12 ; 22)(\mathrm{q} 13 ; \mathrm{q} 12)$ & {$[88]$} \\
\hline & EWS-CREB1 & $\mathrm{t}(2 ; 22)(\mathrm{q} 33 ; \mathrm{q} 12)$ & [89] \\
\hline Desmoplastic Small Round Cell Tumour & EWS-WT1 & $\mathrm{t}(11 ; 22)(\mathrm{p} 13 ; \mathrm{q} 12)$ & {$[90]$} \\
\hline Extraskeletal Myxoid & EWS-CHN1 & $\mathrm{t}(9 ; 22)(\mathrm{q} 22-31 ; \mathrm{q} 11-12)$ & {$[91]$} \\
\hline Chondrosarcoma & EWS-NR4A3 & $\mathrm{t}(9 ; 22)(\mathrm{q} 22 ; \mathrm{q} 12)$ & {$[92]$} \\
\hline Myxoid Liposarcoma & EWS-DDIT3 & $\mathrm{t}(12 ; 22)(\mathrm{q} 13 ; \mathrm{q} 12)$ & [93] \\
\hline
\end{tabular}

demonstrated though the identification of insulin-like growth factor binding protein 3 (IGF-BP3) as a novel p53regulated target gene [113]. Induction of $I G F-B P 3$ gene expression by 553 enhanced secretion of an active form of IGF-BP3 capable of inhibiting IGF1R mitogenic signalling. Thus, the IGF1R signalling pathway is functionally antagonised by wild-type p53. Recent evidence has also shown that IGF1R is degraded by MDM2 [114, 115]. Sequestration of MDM2 in the nucleus by high levels of mutant p53 may be a possible explanation for the high levels of IGF1R observed in some cancers [115].

Interestingly, pharmacological inhibition of IGF1R signalling reduces MDM2 translational synthesis, which in turn stabilizes p53 [116]. IGF1R signalling therefore regulates the p53 pathway. Hence, the overexpression of IGF1R and frequent retention of a functional, wild-type p53 present an opportunity of combined use of specific IGF1R inhibitors with activators of the $\mathrm{p} 53$ pathway.

\section{Pharmacological p53 Activation As a Systemic Therapy for Ewing Sarcoma}

Ewing Sarcomas provide a unique tumor type in which the majority of cases retain the functionally intact p53 pathways that are kept in check by either EWS-FLI1 or through another unknown mechanism. At present, there is no evidence of permanent suppression of the p53 pathway by specific mutation of critical components. Therefore, the most likely scenario involves abrogation of p53 function via a reversible, posttranslational mechanism. This provides unique therapeutic opportunities through intervention with small molecules that directly stabilize and activate endogenous intracellular p53. This concept was first demonstrated using Nutlin-3a, a small molecule antagonist of MDM2, which has shown antitumour activity in vitro and in vivo through activation of the p53 pathway in tumour cells that retain wild-type p53 [117]. Nutlin-3a antagonizes the p53-MDM2 interaction by blocking the p53-binding pocket of MDM2 and as a consequence there is a rapid stabilization and accumulation of p53 protein levels [117]. Promising results from several preclinical studies have clearly demonstrated the therapeutic potential of Nutlin-3a in a variety of tumour types expressing wild-type p53, including liposarcoma [118], rhabdomyosarcoma [119], osteosarcoma [117], synovial sarcoma [120], neuroblastoma [121], retinoblastoma [64], and leukemia [122-124].

We have recently investigated the potential of a p53targeted therapeutic approach for the treatment of Ewing Sarcoma using Nutlin-3a. Interestingly, exposure of Ewing Sarcoma cell lines to Nutlin-3a resulted in a robust apoptotic phenotype [125]. Nutlin-3a induced apoptosis required the presence of a wild-type p53 and did not influence the growth of ESFT cell lines expressing mutant p53. These findings provide confirmation of the functionality of downstream p53 pathways in ESFTs retaining wild-type p53 and suggest that p53 activators will provide a novel molecular-based therapeutic for the majority of ESFTs.

Due to its aggressive nature and early systematic spread, treatment of ESFT is highly challenging. Current treatment protocols for ESFT patients involve multiagent chemotherapy [15]. Prior to the introduction of combinational chemotherapy, 5-year survival for patients diagnosed with ESFT was less than $10 \%$ [126]. Since the introduction of intensive VACD-IE (vincristine, actinomycin D, cyclophosphamide, doxorubicin, etoposide, and ifosfamide) chemotherapy regimens, the current 5-year survival rates for patients with localised disease are ranging from 60 to $70 \%[15,127]$. Nevertheless, Ewing Sarcoma still has the lowest survival rates of any of the musculoskeletal tumours, with minimal improvements to patient outcomes observed over the last decade. Hence, there is an urgent need to develop targeted therapeutic approaches to augment the action of these cytotoxic agents. The integral role of p53 in the DNA damage response pathways stimulated by these genotoxic agents suggests that p53 activators such as Nutlin3a may provide a novel approach to augment intensive 
TABLE 5: Chemical structures and proposed mechanisms of small molecule p53 activators.

Stage in
clinical
testing $\begin{aligned} & \text { Mechanism } \\ & \text { Molecular formula }\end{aligned}$

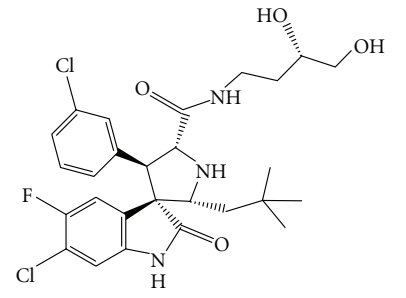

$\mathrm{C}_{27} \mathrm{H}_{32} \mathrm{Cl}_{2} \mathrm{FN}_{3} \mathrm{O}_{4}$

552.5

Binds to MDM2 and inhibits p53-MDM2

Phase I interaction

\section{RITA}<smiles>OCc1ccc(-c2ccc(-c3ccc(CO)s3)o2)s1</smiles><smiles>CN(C)CCCCC(=O)Nc1ccc(NC(=S)N(C)C(=O)c2ccc(C(C)(C)C)cc2)cc1</smiles>

Actinomycin D

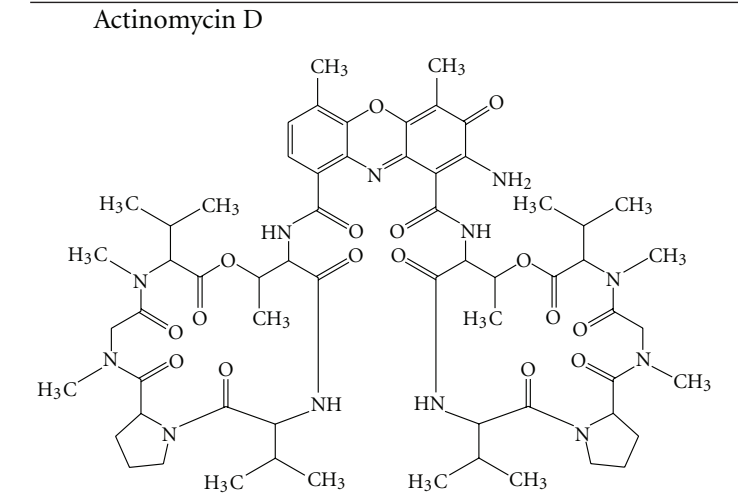

$\mathrm{C}_{62} \mathrm{H}_{86} \mathrm{~N}_{12} \mathrm{O}_{16}$ chemotherapies. Indeed, Nutlin-3a demonstrated synergistic activity with numerous chemotherapies from the VACD-IE protocol in Ewing Sarcoma [125] and in rhabdomyosarcoma [119]. Such encouraging observations will require further evaluation by the conduct of clinical trials using p53 activators as systemic therapies in combination with the current chemotherapy regimens for the treatment of wildtype p53 sarcomas.

The identification of additional drugs that work on the same principle as Nutlin-3a is an area of active research within the p53 community. The majority of reported p53 activators (Table 5 ) have been shown to rapidly stabilize and 
activate $\mathrm{p} 53$ protein levels through inhibition of the MDM2p53 interaction. One such example is the recently identified MI-219, a highly selective MDM2 antagonist [128]. MI219 interacts with the p53 binding pocket of MDM2 with a higher affinity and selectivity than Nutlin-3a and hence attains a more potent stimulation of the p53 pathway. MI-219 was observed to achieve p53-dependent antitumor activity without causing visible signs of toxicity or gross abnormalities in mice [128]. In addition, MI-219 exhibits highly desirable pharmacokinetic properties and is currently in early-phase clinical trials. Small molecule p53 activators can also function through direct interaction with p53, as demonstrated with RITA (Reactivation of p53 and induction of tumour cell apoptosis) [129]. Preclinical studies show that RITA can induce a nongenotoxic activation of p53 through inhibition of the MDM2-p53 interaction via direct interaction with $\mathrm{N}$-terminal domain of p53.

MDM2 antagonists have been demonstrated to elicit their most potent effects in cell lines where MDM2 is amplified or overexpressed [118]. Since this genetic event is not observed in all tumour types, small molecules that activate p53 through alternative pathways have been developed. Lain and colleagues identified the Tenovins, a class of p53 activators that enhance the acetylation of p53 [130]. The mechanism of action of Tenovin- 1 and the water soluble analog Tenovin- 6 involve the direct inhibition of SIRT1 and SIRT2, two members of the sirtuin family of class III histone deacetylases responsible for the deacetylation of p53 [131133]. It is widely accepted that acetylation is an indispensible modification of p53 that occurs during specific activation of the p53 pathway $[134,135]$. Interestingly, Tenovin-6 was shown to repress the growth of cancer cells using in vitro and in vivo models through hyperacetylation of p53 [130]. These studies imply that pharmacological inhibition of sitrins is an effective approach for p53 activation.

Although specific p53 activation in tumours is an attractive therapeutic approach, these recently developed small molecules are under investigation in preclinical or early-phase clinical trials. In an attempt to accelerate the implementation of p53 activators in the clinic, a study led by Choong and colleagues screened a library of clinically approved drugs and successfully identified actinomycin D as a compound which mimics the action of Nutlin-3a when administered at specific dosages [136]. Surprisingly, low doses of actinomycin D induced specific activation of the p53 pathway with cellular responses remarkably similar to that of Nutlin-3a. These concentrations of actinomycin D were also demonstrated to augment the cytotoxic actions of chemotherapeutic drugs in cancer cells with wild-type p53 [136]. As actinomycin D is an FDA-approved drug, these findings catalyze the immediate application of a p53-based targeted therapeutic approach in the clinic.

High doses of actinomycin D are associated with intercalation into the DNA and subsequent double-strand DNA breaks [137]. It is presently used in the clinic as a chemotherapeutic agent and is a component of the highly successful combination treatment for Wilm's tumour. The inclusion of actinomycin D in current multiagent chemotherapy regimes for Ewing Sarcoma is variable amongst different clinical centers and is often dependent on the age of the patient. Since the pharmacokinetic data available for actinomycin $\mathrm{D}$ is limited $[138,139]$, comparison between the required in vivo dosages of this drug with the low concentrations used in vitro which elicit specific activation of $\mathrm{p} 53$ remains a formidable challenge. Interestingly, Ewing Sarcoma cells are highly sensitive to actinomycin $\mathrm{D}$ in vitro, with potent antitumour activity observed within the ranges described as "low dose" specifically in Ewing Sarcoma cell line that retains wild type p53 [125]. Further studies are warranted to evaluate the potential of incorporation of low dose actinomycin D with the current standard of care for the treatment of patients with wild-type p53 ESFTs.

\section{Conclusion}

Ewing Sarcomas share the common genetic features including the universal presence of the EWS-ETS translocation and frequent retention of the wild-type p53 and its associated functional downstream pathways. Targeted exploitation of the p53 pathway holds great promise to enhance the activity of current ESFT treatment regimes and improve the currently poor survival rates associated with Ewing Sarcoma. Recent identification of the first clinically approved drug, actinomycin D, as a p53 activator has facilitated the translation of these targeted therapies into current ESFT treatment regimens. Low dose actinomycin D hold an exciting potential as a directed molecular-based approach to specifically activate wild-type p53 in ESFTs, and the organization of clinical trials currently in progress to attest the potential of this approach. In addition, complementation of these studies with direct TP53 sequencing of ESFT material would identify either patients with wild-type p53 tumours most likely to benefit from p53-based therapies or the less frequent "high risk" population of ESFTs containing point mutations in the TP53 gene.

\section{Acknowledgment}

This study was supported in part by the Australasian Sarcoma Study Group Sarcoma Research Award funded through the Rainbows for Kate foundation in memory of Tom Wood.

\section{References}

[1] D. P. Lane, "p53, guardian of the genome," Nature, vol. 358, no. 6381, pp. 15-16, 1992.

[2] K. H. Vousden and C. Prives, "Blinded by the light: the growing complexity of p53," Cell, vol. 137, no. 3, pp. 413431, 2009.

[3] B. Vogelstein and K. W. Kinzler, "Cancer genes and the pathways they control," Nature Medicine, vol. 10, no. 8, pp. 789-799, 2004.

[4] B. Vogelstein, D. Lane, and A. J. Levine, "Surfing the p53 network," Nature, vol. 408, no. 6810, pp. 307-310, 2000.

[5] H. Kovar, A. Auinger, G. Jug et al., "Narrow spectrum of infrequent p53 mutations and absence of MDM2 amplification in Ewing tumours," Oncogene, vol. 8, no. 10, pp. 26832690, 1993. 
[6] H. Komuro, Y. Hayashi, M. Kawamura et al., "Mutations of the p53 gene are involved in Ewing's sarcomas but not in neuroblastomas," Cancer Research, vol. 53, no. 21, pp. 5284 5288, 1993.

[7] R. Hamelin, J. Zucman, T. Melot, O. Delatire, and G. Thomas, "p53 Mutations in human tumors with chimeric EWS/FLI-1 genes," International Journal of Cancer, vol. 57, no. 3, pp. 336-340, 1994.

[8] A. Patiño-García and L. Sierrasesúmaga, "Analysis of the p16INK4 and TP53 tumor suppressor genes in bone sarcoma pediatric patients," Cancer Genetics and Cytogenetics, vol. 98, no. 1, pp. 50-55, 1997.

[9] K. Radig, R. Schneider-Stock, I. Röse, U. Mittler, Y. Oda, and A. Roessner, "p53 and ras mutations in Ewing's sarcoma," Pathology Research and Practice, vol. 194, no. 3, pp. 157-162, 1998.

[10] T. Tsuchiya, K. Sekine, S. Hinohara, T. Namiki, T. Nobori, and Y. Kaneko, "Analysis of the p16INK4, p14ARF, p15, TP53, and MDM2 genes and their prognostic implications in osteosarcoma and Ewing sarcoma," Cancer Genetics and Cytogenetics, vol. 120, no. 2, pp. 91-98, 2000.

[11] J. A. López-Guerrero, A. Pellín, R. Noguera, C. Carda, and A. Llombart-Bosch, "Molecular analysis of the 9p21 locus and p53 genes in Ewing family tumors," Laboratory Investigation, vol. 81, no. 6, pp. 803-814, 2001.

[12] H.-Y. Huang, P. B. Illei, Z. Zhao et al., "Ewing sarcomas with p53 mutation or p16/p14ARF homozygous deletion: a highly lethal subset associated with poor chemoresponse," Journal of Clinical Oncology, vol. 23, no. 3, pp. 548-558, 2005.

[13] Y.-K. Park, S. G. Chi, Y. W. Kim, H. R. Park, and K. K. Unni, "P53 mutations in Ewing's sarcoma," Oncology Reports, vol. 8, no. 3, pp. 533-537, 2001.

[14] K.-L. Schaefer, M. Eisenacher, Y. Braun et al., "Microarray analysis of Ewing's sarcoma family of tumours reveals characteristic gene expression signatures associated with metastasis and resistance to chemotherapy," European Journal of Cancer, vol. 44, no. 5, pp. 699-709, 2008.

[15] Y. Iwamoto, "Diagnosis and treatment of Ewing's sarcoma," Japanese Journal of Clinical Oncology, vol. 37, no. 2, pp. 7989, 2007.

[16] N. Riggi and I. Stamenkovic, "The biology of Ewing sarcoma," Cancer Letters, vol. 254, no. 1, pp. 1-10, 2007.

[17] C. D. M. Fletcher, P. Gustafson, A. Rydholm, H. Willén, and M. Åkerman, "Clinicopathologic re-evaluation of 100 malignant fibrous histiocytomas: prognostic relevance of subclassification," Journal of Clinical Oncology, vol. 19, no. 12, pp. 3045-3050, 2001.

[18] S. Pilotti, G. Della Torre, C. Lavarino et al., "Distinct $\mathrm{mdm} 2 / \mathrm{p} 53$ expression in patterns in liposarcoma subgroups: implications for different pathogenetic mechanisms," Journal of Pathology, vol. 181, no. 1, pp. 14-24, 1997.

[19] A. P. Dei Tos, C. Doglioni, S. Piccinin et al., "Molecular abnormalities of the $\mathrm{p} 53$ pathway in dedifferentiated liposarcoma," Journal of Pathology, vol. 181, no. 1, pp. 8-13, 1997.

[20] R. Schneider-Stock, H. Walter, J. Rys, K. Radig, C. Hoang-Vu, and A. Roessner, "No correlation of c-myc overexpression and p53 mutations in liposarcomas," Virchows Archiv, vol. 433, no. 4, pp. 315-321, 1998.

[21] R. Schneider-Stock, A. Ziegeler, C. Haeckel, D.-S. Franke, J. Rys, and A. Roessner, "Prognostic relevance of p53 alterations and Mib-1 proliferation index in subgroups of primary liposarcomas," Clinical Cancer Research, vol. 5, no. 10, pp. 2830-2835, 1999.
[22] J. Barretina, B. S. Taylor, S. Banerji et al., "Subtypespecific genomic alterations define new targets for soft-tissue sarcoma therapy," Nature Genetics, vol. 42, no. 8, pp. 715$721,2010$.

[23] Y. Oda, H. Yamamoto, T. Takahira et al., "Frequent alteration of p16INK4a/p14ARF and p53 pathways in the round cell component of myxoid/round cell liposarcoma: p53 gene alterations and reduced p14ARF expression both correlate with poor prognosis," Journal of Pathology, vol. 207, no. 4, pp. 410-421, 2005.

[24] J. Toguchida, T. Yamaguchi, B. Ritchie et al., "Mutation spectrum of the p53 gene in bone and soft tissue sarcomas," Cancer Research, vol. 52, no. 22, pp. 6194-6199, 1992.

[25] E. Latres, M. Drobnjak, D. Pollack et al., "Chromosome 17 abnormalities and TP53 mutations in adult soft tissue sarcomas," American Journal of Pathology, vol. 145, no. 2, pp. 345-355, 1994.

[26] J. S. Castresana, M.-P. Rubio, L. Gomez, A. Kreicbergs, A. Zetterberg, and C. Barrios, "Detection of TP53 gene mutations in human sarcomas," European Journal of Cancer A, vol. 31, no. 5, pp. 735-738, 1995.

[27] G. Nawa, Y. Miyoshi, H. Yoshikawa, T. Ochi, and Y. Nakamura, "Frequent loss of expression or aberrant alternative splicing of P2XM, a p53-inducible gene, in soft-tissue tumours," British Journal of Cancer, vol. 80, no. 8, pp. 11851189, 1999.

[28] P. Das, D. Kotilingam, B. Korchin et al., "High prevalence of p53 exon 4 mutations in soft tissue sarcoma," Cancer, vol. 109, no. 11, pp. 2323-2333, 2007.

[29] C. A. Felix, C. C. Kappel, T. Mitsudomi et al., "Frequency and diversity of p53 mutations in childhood rhabdomyosarcoma," Cancer Research, vol. 52, no. 8, pp. 2243-2247, 1992.

[30] T. Kusafuka, M. Fukuzawa, T. Oue, Y. Komoto, A. Yoneda, and A. Okada, "Mutation analysis of p53 gene in childhood malignant solid tumors," Journal of Pediatric Surgery, vol. 32, no. 8, pp. 1175-1180, 1997.

[31] J. Mora, A. M. Dobrenis, J. B. Bussel, and A. Aledo, "p53 mutation and MDM2 amplification frequency pediatric rhabdomyosarcoma tumors and cell lines," Medical and Pediatric Oncology, vol. 35, no. 2, pp. 96-103, 2000.

[32] Y. Takahashi, Y. Oda, K.-I. Kawaguchi et al., "Altered expression and molecular abnormalities of cell-cycle-regulatory proteins in rhabdomyosarcoma," Modern Pathology, vol. 17, no. 6, pp. 660-669, 2004.

[33] R. Schneider-Stock, K. Radig, Y. Oda et al., "p53 gene mutations in soft-tissue sarcomas-correlations with p53 immunohistochemistry and DNA ploidy," Journal of Cancer Research and Clinical Oncology, vol. 123, no. 4, pp. 211-218, 1997.

[34] A. P. Dei Tos, C. Doglioni, G. Muffato et al., "Synovial sarcoma exhibits deregulation of the G1-S cell cycle checkpoint and of the apoptotic pathway," Modern Pathology, vol. 12, p. 10A, 1999.

[35] R. Schneider-Stock, D. Onnasch, C. Haeckel, W. Mellin, D.-S. Franke, and A. Roessner, "Prognostic significance of p53 gene mutations and p53 protein expression in synovial sarcomas," Virchows Archiv, vol. 435, no. 4, pp. 407-412, 1999.

[36] Y. Oda, A. Sakamoto, T. Satio, S. Kawauchi, Y. Iwamoto, and M. Tsuneyoshi, "Molecular abnormalities of p53, MDM2, and H-ras synovial sarcoma," Modern Pathology, vol. 13, no. 9, pp. 994-1004, 2000.

[37] A. Andreassen, T. Oyjord, E. Hovig et al., "p53 Abnormalities in different subtypes of human sarcomas," Cancer Research, vol. 53, no. 3, pp. 468-471, 1993. 
[38] F. S. Leach, T. Tokino, P. Meltzer et al., "p53 Mutation and MDM2 amplification in human soft tissue sarcomas," Cancer Research, vol. 53, no. 10, pp. 2231-2234, 1993.

[39] H. Patterson, S. Gill, C. Fisher et al., "Abnormalities of the p53 MDM2 and DCC genes in human leiomyosarcomas," British Journal of Cancer, vol. 69, no. 6, pp. 1052-1058, 1994.

[40] C. W. Miller, A. Aslo, A. Won, M. Tan, B. Lampkin, and H. P. Koeffler, "Alterations of the p53, Rb and MDM2 genes in osteosarcoma," Journal of Cancer Research and Clinical Oncology, vol. 122, no. 9, pp. 559-565, 1996.

[41] K. L. Hall, M. G. Teneriello, R. R. Taylor et al., "Analysis of Ki-ras, p53, and MDM2 genes in uterine leiomyomas and leiomyosarcomas," Gynecologic Oncology, vol. 65, no. 2, pp. 330-335, 1997.

[42] Y.-L. Zhai, T. Nikaido, T. Toki, A. Shiozawa, A. Orii, and S. Fujii, "Prognostic significance of bcl-2 expression in leiomyosarcoma of the uterus," British Journal of Cancer, vol. 80, no. 10, pp. 1658-1664, 1999.

[43] K. Miyajima, S. Tamiya, Y. Oda et al., "Relative quantitation of p53 and MDM2 gene expression in leiomyosarcoma; real-time semi-quantitative reverse transcriptionpolymerase chain reaction," Cancer Letters, vol. 164, no. 2, pp. 177-188, 2001.

[44] N. Gokgoz, J. S. Wunder, S. Mousses, S. Eskandarian, R. S. Bell, and I. L. Andrulis, "Comparison of p53 mutations in patients with localized osteosarcoma and metastatic osteosarcoma," Cancer, vol. 92, no. 8, pp. 2181-2189, 2001.

[45] M. Overholtzer, P. H. Rao, R. Favis et al., "The presence of p53 mutations in human osteosarcomas correlates with high levels of genomic instability," Proceedings of the National Academy of Sciences of the United States of America, vol. 100, no. 20, pp. 11547-11552, 2003.

[46] A. Petitjean, M. I. W. Achatz, A. L. Borresen-Dale, P. Hainaut, and M. Olivier, “TP53 mutations in human cancers: functional selection and impact on cancer prognosis and outcomes," Oncogene, vol. 26, no. 15, pp. 2157-2165, 2007.

[47] D. P. Lane, "p53 and human cancers," British Medical Bulletin, vol. 50, no. 3, pp. 582-599, 1994.

[48] J. A. Lopez-Guerrero, I. Machado, K. Scotlandi et al., "Clinicopathological significance of cell cycle regulation markers in a large series of genetically confirmed Ewing's Sarcoma Family of Tumors," International Journal of Cancer. In press.

[49] L. M. Mulligan, G. J. Matlashewski, H. J. Scrable, and W. K. Cavenee, "Mechanisms of p53 loss in human sarcomas," Proceedings of the National Academy of Sciences of the United States of America, vol. 87, no. 15, pp. 5863-5867, 1990.

[50] C. W. Miller, A. Aslo, C. Tsay et al., "Frequency and structure of p53 rearrangements in human osteosarcoma," Cancer Research, vol. 50, no. 24, pp. 7950-7954, 1990.

[51] J. Momand, D. Jung, S. Wilczynski, and J. Niland, "The MDM2 gene amplification database," Nucleic Acids Research, vol. 26, no. 15, pp. 3453-3459, 1998.

[52] X. Wu, J. H. Bayle, D. Olson, and A. J. Levine, "The p53mdm-2 autoregulatory feedback loop," Genes and Development, vol. 7, no. 7, pp. 1126-1132, 1993.

[53] Y. Haupt, R. Maya, A. Kazaz, and M. Oren, "Mdm2 promotes the rapid degradation of p53," Nature, vol. 387, no. 6630, pp. 296-299, 1997.

[54] M. H. G. Kubbutat, S. N. Jones, and K. H. Vousden, "Regulation of p53 stability by Mdm2," Nature, vol. 387, no. 6630, pp. 299-303, 1997.
[55] F. Pedeutour, A. Forus, J.-M. Coindre et al., "Structure of the supernumerary ring and giant rod chromosomes in adipose tissue tumors," Genes Chromosomes and Cancer, vol. 24, no. 1, pp. 30-41, 1999.

[56] F. J. Stott, S. Bates, M. C. James et al., "The alternative product from the human CDKN2A locus, p14(ARF), participates in a regulatory feedback loop with p53 and MDM2," The EMBO Journal, vol. 17, no. 17, pp. 5001-5014, 1998.

[57] J. Pomerantz, N. Schreiber-Agus, N. J. Liégeois et al., "The Ink4a tumor suppressor gene product, p19(Arf), interacts with MDM2 and neutralizes MDM2's inhibition of p53," Cell, vol. 92, no. 6, pp. 713-723, 1998.

[58] M. Ladanyi, R. Lewis, S. C. Jhanwar, W. Gerald, A. G. Huvos, and J. H. Healey, "MDM2 and CDK4 gene amplification in Ewing's sarcoma," Journal of Pathology, vol. 175, no. 2, pp. 211-217, 1995.

[59] G. Wei, C. R. Antonescu, E. De Alava et al., "Prognostic impact of INK4A deletion in Ewing sarcoma," Cancer, vol. 89, no. 4, pp. 793-799, 2000.

[60] S. C. Brownhill, C. Taylor, and S. A. Burchill, "Chromosome 9p21 gene copy number and prognostic significance of p16 in ESFT," British Journal of Cancer, vol. 96, no. 12, pp. 19141923, 2007.

[61] F. Bartel, J. Schulz, A. Böhnke et al., "Significance of HDMX$S$ (or MDM4) mRNA splice variant overexpression and HDMX gene amplification on primary soft tissue sarcoma prognosis," International Journal of Cancer, vol. 117, no. 3, pp. 469-475, 2005.

[62] D. Danovi, E. Meulmeester, D. Pasini et al., "Amplification of Mdmx (or Mdm4) directly contributes to tumor formation by inhibiting p53 tumor suppressor activity," Molecular and Cellular Biology, vol. 24, no. 13, pp. 5835-5843, 2004.

[63] A. Shvarts, M. Bazuine, P. Dekker et al., "Isolation and identification of the human homolog of a new p53-binding protein, Mdmx," Genomics, vol. 43, no. 1, pp. 34-42, 1997.

[64] N. A. Laurie, S. L. Donovan, C.-S. Shih et al., "Inactivation of the p53 pathway in retinoblastoma," Nature, vol. 444, no. 7115, pp. 61-66, 2006.

[65] P. A.J. Muller, P. T. Caswell, B. Doyle et al., "Mutant p53 drives invasion by promoting integrin recycling," Cell, vol. 139, no. 7, pp. 1327-1341, 2009.

[66] H. Kovar, S. Pospisilova, G. Jug, D. Printz, and H. Gadner, "Response of Ewing tumor cells to forced and activated p53 expression," Oncogene, vol. 22, no. 21, pp. 3193-3204, 2003.

[67] M. Ladanyi, "EWS-FLI1 and Ewing's sarcoma: recent molecular data and new insights," Cancer Biology \& Therapy, vol. 1, no. 4, pp. 330-336, 2002.

[68] A. Abudu, D. C. Mangham, G. M. Reynolds et al., "Overexpression of p53 protein in primary Ewing's sarcoma of bone: relationship to tumour stage, response and prognosis," British Journal of Cancer, vol. 79, no. 7-8, pp. 1185-1189, 1999.

[69] E. de Alava, C. R. Antonescu, A. Panizo et al., "Prognostic impact of P53 status in Ewing sarcoma," Cancer, vol. 89, no. 4, pp. 783-792, 2000.

[70] T. Ozaki, M. Paulussen, C. Poremba et al., "Genetic imbalances revealed by comparative genomic hybridization in Ewing tumors," Genes Chromosomes and Cancer, vol. 32, no. 2, pp. 164-171, 2001.

[71] S. Savola, A. Klami, A. Tripathi et al., "Combined use of expression and CGH arrays pinpoints novel candidate genes in Ewing sarcoma family of tumors," BMC Cancer, vol. 9, article 17, 2009. 
[72] P. M. Neilsen, K. M. Cheney, C.-W. Li et al., "Identification of ANKRD11 as a p53 coactivator," Journal of Cell Science, vol. 121, no. 21, pp. 3541-3552, 2008.

[73] O. Delattre, J. Zucman, B. Plougastel et al., "Gene fusion with an ETS DNA-binding domain caused by chromosome translocation in human tumours," Nature, vol. 359, no. 6391, pp. 162-165, 1992.

[74] J. Zucman, T. Melot, C. Desmaze et al., "Combinatorial generation of variable fusion proteins in the Ewing family of tumours," The EMBO Journal, vol. 12, no. 12, pp. 4481-4487, 1993.

[75] H. Kovar, D. N. T. Aryee, G. Jug et al., "EWS/FLI-1 antagonists induce growth inhibition of Ewing tumor cells in vitro," Cell Growth and Differentiation, vol. 7, no. 4, pp. 429-437, 1996.

[76] M. Ouchida, T. Ohno, Y. Fujimura, V. N. Rao, and E. S. P. Reddy, "Loss of tumorigenicity of Ewing's sarcoma cells expressing antisense RNA to EWS-fusion transcripts," Oncogene, vol. 11, no. 6, pp. 1049-1054, 1995.

[77] K. Tanaka, T. Iwakuma, K. Harimaya, H. Sato, and Y. Iwamoto, "EWS-Fli1 antisense oligodeoxynucleotide inhibits proliferation of human Ewing's sarcoma and primitive neuroectodermal tumor cells," The Journal of Clinical Investigation, vol. 99, no. 2, pp. 239-247, 1997.

[78] J. A. Toretsky, Y. Connell, L. Neckers, and N. K. Bhat, "Inhibition of EWS-FLI-1 fusion protein with antisense oligodeoxynucleotides," Journal of Neuro-Oncology, vol. 31, no. 1-2, pp. 9-16, 1997.

[79] J. Ban, I. M. Bennani-Baiti, M. Kauer et al., "EWS-FLI1 suppresses NOTCH-activated p53 in Ewing's sarcoma," Cancer Research, vol. 68, no. 17, pp. 7100-7109, 2008.

[80] Y. Li, K. Tanaka, X. Fan et al., "Inhibition of the transcriptional function of $\mathrm{p} 53$ by EWS-Fli1 chimeric protein in Ewing Family Tumors," Cancer Letters, vol. 294, no. 1, pp. 57-65, 2010.

[81] P. H. B. Sorensen, S. L. Lessnick, D. Lopez-Terrada, X. F. Liu, T. J. Triche, and C. T. Denny, "A second Ewing's sarcoma translocation, $\mathrm{t}(21 ; 22)$, fuses the EWS gene to another ETSfamily transcription factor, ERG," Nature Genetics, vol. 6, no. 2, pp. 146-151, 1994.

[82] I.-S. Jeon, J. N. Davis, B. S. Braun et al., “A variant Ewing's sarcoma translocation $(7 ; 22)$ fuses the EWS gene to the ETS gene ETV1," Oncogene, vol. 10, no. 6, pp. 1229-1234, 1995.

[83] Y. Kaneko, K. Yoshida, M. Handa et al., "Fusion of an ETSfamily gene, EIAF, to EWS by $\mathrm{t}(17 ; 22)(\mathrm{q} 12 ; \mathrm{q} 12)$ chromosome translocation in an undifferentiated sarcoma of infancy," Genes Chromosomes and Cancer, vol. 15, no. 2, pp. 115-121, 1996.

[84] M. Peter, J. Couturier, H. Pacquement et al., "A new member of the ETS family fused to EWS in Ewing tumors," Oncogene, vol. 14, no. 10, pp. 1159-1164, 1997.

[85] A. Martini, R. La Starza, H. Janssen et al., "Recurrent rearrangement of the Ewing's sarcoma gene, EWSR1, or its homologue, TAF15, with the transcription factor CIZ/NMP4 in acute leukemia," Cancer Research, vol. 62, no. 19, pp. 54085412, 2002.

[86] K. H. Hallor, F. Mertens, Y. Jin et al., "Fusion of the EWSR1 and ATF1 genes without expression of the MITF$\mathrm{M}$ transcript in angiomatoid fibrous histiocytoma," Genes Chromosomes and Cancer, vol. 44, no. 1, pp. 97-102, 2005.

[87] S. Rossi, K. Szuhai, M. Ijszenga et al., "EWSR1-CREB1 and EWSR1-ATF1 fusion genes in angiomatoid fibrous histiocytoma," Clinical Cancer Research, vol. 13, no. 24, pp. 7322-7328, 2007.
[88] J. Zucman, O. Delattre, C. Desmaze et al., "EWS and ATF-1 gene fusion induced by $\mathrm{t}(12 ; 22)$ translocation in malignant melanoma of soft parts," Nature Genetics, vol. 4, no. 4, pp. 341-345, 1993.

[89] C. R. Antonescu, K. Nafa, N. H. Segal, P. Dal Cin, and M. Ladanyi, "EWS-CREB1: a recurrent variant fusion in clear cell sarcoma-association with gastrointestinal location and absence of melanocytic differentiation," Clinical Cancer Research, vol. 12, no. 18, pp. 5356-5362, 2006.

[90] M. Ladanyi and W. Gerald, "Fusion of the EWS and WT1 genes in the desmoplastic small round cell tumor," Cancer Research, vol. 54, no. 11, pp. 2837-2840, 1994.

[91] J. Clark, H. Benjamin, S. Gill et al., "Fusion of the EWS gene to $\mathrm{CHN}$, a member of the steroid/thyroid receptor gene superfamily, in a human myxoid chondrosarcoma," Oncogene, vol. 12, no. 2, pp. 229-235, 1996.

[92] C. Orndal, B. Carlen, M. Akerman et al., "Chromosomal abnormaity $\mathrm{t}(9 ; 22)(\mathrm{q} 22 ; \mathrm{q} 12)$ in an extraskeletal myxoid chondrosarcoma characterized by fine needle aspiration cytology, electron microscopy, immunohistochemistry and DNA flow cytometry," Cytopathology, vol. 2, no. 5, pp. 261270, 1991.

[93] I. Panagopoulos, M. Höglund, F. Mertens, N. Mandahl, F. Mitelman, and P. Åman, "Fusion of the EWS and CHOP genes in myxoid liposarcoma," Oncogene, vol. 12, no. 3, pp. 489-494, 1996.

[94] C. Turc-Carel, P. Dal Cin, J. Limon, F. Li, and A. A. Sandberg, "Translocation X;18 in synovial sarcoma," Cancer Genetics and Cytogenetics, vol. 23, no. 1, p. 93, 1986.

[95] P. D’Arcy, W. Maruwge, B. A. Ryan, and B. Brodin, "The oncoprotein SS18-SSX1 promotes p53 ubiquitination and degradation by enhancing HDM2 stability," Molecular Cancer Research, vol. 6, no. 1, pp. 127-138, 2008.

[96] S. L. Lessnick, C. S. Dacwag, and T. R. Golub, “The Ewing's sarcoma oncoprotein EWS/FLI induces a p53-dependent growth arrest in primary human fibroblasts," Cancer Cell, vol. 1, no. 4, pp. 393-401, 2002.

[97] B. Deneen and C. T. Denny, "Loss of p16 pathways stabilizes EWS/FLI1 expression and complements EWS/FLI1 mediated transformation," Oncogene, vol. 20, no. 46, pp. 6731-6741, 2001.

[98] M. Braig and C. A. Schmitt, "Oncogene-induced senescence: putting the brakes on tumor development," Cancer Research, vol. 66, no. 6, pp. 2881-2884, 2006.

[99] A. Sala, I. Casella, L. Grasso et al., "Apoptotic response to oncogenic stimuli: cooperative and antagonistic interactions between c-myb and the growth suppressor p53," Cancer Research, vol. 56, no. 9, pp. 1991-1996, 1996.

[100] M. Kauer, J. Ban, R. Kofler et al., "A molecular function map of Ewing's sarcoma," PLoS ONE, vol. 4, no. 4, Article ID e5415, 2009.

[101] Y. Castillero-Trejo, S. Eliazer, L. Xiang, J. A. Richardson, and R. L. Ilaria Jr., "Expression of the EWS/FLI-1 oncogene in murine primary bone-derived cells results in EWS/FLI1-dependent, Ewing sarcoma-like tumors," Cancer Research, vol. 65, no. 19, pp. 8698-8705, 2005.

[102] N. Riggi, L. Cironi, P. Provero et al., "Development of Ewing's sarcoma from primary bone marrow-derived mesenchymal progenitor cells," Cancer Research, vol. 65, no. 24, pp. 1145911468, 2005.

[103] N. Riggi, M.-L. Suvà, D. Suvà et al., "EWS-FLI-1 expression triggers a ewing's sarcoma initiation program in primary human mesenchymal stem cells," Cancer Research, vol. 68, no. 7, pp. 2176-2185, 2008. 
[104] P. P. Lin, M. K. Pandey, F. Jin et al., "EWS-FLI1 induces developmental abnormalities and accelerates sarcoma formation in a transgenic mouse model," Cancer Research, vol. 68, no. 21, pp. 8968-8975, 2008.

[105] R. Baserga, "The insulin-like growth factor I receptor: a key to tumor growth?" Cancer Research, vol. 55, no. 2, pp. 249$252,1995$.

[106] R. Baserga, M. Resnicoff, and M. Dews, "The IGF-I receptor and cancer," Endocrine, vol. 7, no. 1, pp. 99-102, 1997.

[107] H. Werner and D. L. Roith, "The insulin-like growth factor-I receptor signaling pathways are important for tumorigenesis and inhibition of apoptosis," Critical Reviews in Oncogenesis, vol. 8, no. 1, pp. 71-92, 1997.

[108] A. Prieur, F. Tirode, P. Cohen, and O. Delattre, "EWS/FLI-1 silencing and gene profiling of Ewing cells reveal downstream oncogenic pathways and a crucial role for repression of insulin-like growth factor binding protein 3," Molecular and Cellular Biology, vol. 24, no. 16, pp. 7275-7283, 2004.

[109] D. M. Thomas and A. J. Wagner, "Specific targets in sarcoma and developmental therapeutics," JNCCN Journal of the National Comprehensive Cancer Network, vol. 8, no. 6, pp. 677-685, 2010.

[110] A. W. Tolcher, J. Sarantopoulos, A. Patnaik et al., "Phase I, pharmacokinetic, and pharmacodynamic study of AMG 479, a fully human monoclonal antibody to insulin-like growth factor receptor 1," Journal of Clinical Oncology, vol. 27, no. 34, pp. 5800-5807, 2009.

[111] D. Olmos, S. Postel-Vinay, L. R. Molife et al., "Safety, pharmacokinetics, and preliminary activity of the anti-IGF1R antibody figitumumab (CP-751,871) in patients with sarcoma and Ewing's sarcoma: a phase 1 expansion cohort study," The Lancet Oncology, vol. 11, no. 2, pp. 129-135, 2010.

[112] H. Werner, E. Karnieli, F. J. Rauscher III, and D. LeRoith, "Wild-type and mutant p53 differentially regulate transcription of the insulin-like growth factor I receptor gene," Proceedings of the National Academy of Sciences of the United States of America, vol. 93, no. 16, pp. 8318-8323, 1996.

[113] L. Buckbinder, R. Talbott, S. Velasco-Miguel et al., "Induction of the growth inhibitor IGF-binding protein 3 by p53," Nature, vol. 377, no. 6550, pp. 646-649, 1995.

[114] P. Froment, J. Dupont, and J. Christophe-Marine, "Mdm2 exerts pro-apoptotic activities by antagonizing insulin-like growth factor-I-mediated survival," Cell Cycle, vol. 7, no. 19, pp. 3098-3103, 2008.

[115] L. Girnita, A. Girnita, and O. Larsson, "Mdm2-dependent ubiquitination and degradation of the insulin-like growth factor 1 receptor," Proceedings of the National Academy of Sciences of the United States of America, vol. 100, no. 14, pp. 8247-8252, 2003.

[116] L. Xiong, F. Kou, Y. Yang, and J. Wu, "A novel role for IGF-1R in p53-mediated apoptosis through translational modulation of the p53-Mdm2 feedback loop," Journal of Cell Biology, vol. 178, no. 6, pp. 995-1007, 2007.

[117] L. T. Vassilev, B. T. Vu, B. Graves et al., "In vivo activation of the p53 pathway by small-molecule antagonists of MDM2," Science, vol. 303, no. 5659, pp. 844-848, 2004.

[118] C. R. Müller, E. B. Paulsen, P. Noordhuis, F. Pedeutour, G. Sæter, and O. Myklebost, "Potential for treatment of liposarcomas with the MDM2 antagonist Nutlin-3A," International Journal of Cancer, vol. 121, no. 1, pp. 199-205, 2007.

[119] M. Miyachi, N. Kakazu, S. Yagyu et al., "Restoration of p53 pathway by nutlin-3 induces cell cycle arrest and apoptosis in human rhabdomyosarcoma cells," Clinical Cancer Research, vol. 15, no. 12, pp. 4077-4084, 2009.
[120] P. D'Arcy, B. A. Ryan, and B. Brodin, "Reactivation of p53 function in synovial sarcoma cells by inhibition of p53HDM2 interaction," Cancer Letters, vol. 275, no. 2, pp. 285292, 2009.

[121] T. Van Maerken, F. Speleman, J. Vermeulen et al., "Smallmolecule MDM2 antagonists as a new therapy concept for neuroblastoma," Cancer Research, vol. 66, no. 19, pp. 96469655, 2006.

[122] L. Coll-Mulet, D. Iglesias-Serret, A. F. Santidrián et al., "MDM2 antagonists activate p53 and synergize with genotoxic drugs in B-cell chronic lymphocytic leukemia cells," Blood, vol. 107, no. 10, pp. 4109-4114, 2006.

[123] L. Gu, N. Zhu, H. W. Findley, and M. Zhou, "MDM2 antagonist nutlin-3 is a potent inducer of apoptosis in pediatric acute lymphoblastic leukemia cells with wild-type p53 and overexpression of MDM2," Leukemia, vol. 22, no. 4, pp. 730-739, 2008.

[124] K. Kojima, M. Konopleva, I. J. Samudio et al., "MDM2 antagonists induce p53-dependent apoptosis in AML: implications for leukemia therapy," Blood, vol. 106, no. 9, pp. 3150-3159, 2005.

[125] K. I. Pishas, F. Al-Ejeh, I. Zinonos et al., "Nutlin-3a is a potential therapeutic for Ewing Sarcoma," Clinical Cancer Research. In press.

[126] G. Rosen, N. Wollner, and C. Tan, "Disease free survival in children with Ewing's sarcoma treated with radiation therapy and adjuvant four drug sequential chemotherapy," Cancer, vol. 33, no. 2, pp. 384-393, 1974.

[127] H. E. Grier, M. D. Krailo, N. J. Tarbell et al., "Addition of ifosfamide and etoposide to standard chemotherapy for Ewing's sarcoma and primitive neuroectodermal tumor of bone," New England Journal of Medicine, vol. 348, no. 8, pp. 694-701, 2003.

[128] S. Shangary, D. Qin, D. McEachern et al., "Temporal activation of p53 by a specific MDM2 inhibitor is selectively toxic to tumors and leads to complete tumor growth inhibition," Proceedings of the National Academy of Sciences of the United States of America, vol. 105, no. 10, pp. 3933-3938, 2008.

[129] N. Issaeva, P. Bozko, M. Enge et al., "Small molecule RITA binds to p53, blocks p53-HDM-2 interaction and activates p53 function in tumors," Nature Medicine, vol. 10, no. 12, pp. 1321-1328, 2004.

[130] S. Lain, J. J. Hollick, J. Campbell et al., "Discovery, in vivo activity, and mechanism of action of a small-molecule p53 activator," Cancer Cell, vol. 13, no. 5, pp. 454-463, 2008.

[131] E. Langley, M. Pearson, M. Faretta et al., "Human SIR2 deacetylates p53 and antagonizes PML/p53-induced cellular senescence," The EMBO Journal, vol. 21, no. 10, pp. 23832396, 2002.

[132] A. Vaquero, M. B. Scher, H. L. Dong et al., "SirT2 is a histone deacetylase with preference for histone H4 Lys 16 during mitosis," Genes and Development, vol. 20, no. 10, pp. 12561261, 2006.

[133] H. Vaziri, S. K. Dessain, E. N. Eaton et al., "hSIR2SIRT1 functions as an NAD-dependent p53 deacetylase," Cell, vol. 107, no. 2, pp. 149-159, 2001.

[134] Y. Tang, J. Luo, W. Zhang, and W. Gu, “TTip60-dependent acetylation of p53 modulates the decision between cell-cycle arrest and apoptosis," Molecular Cell, vol. 24, no. 6, pp. 827839, 2006.

[135] Y. Tang, W. Zhao, Y. Chen, Y. Zhao, and W. Gu, "Acetylation is indispensable for p53 activation," Cell, vol. 133, no. 4, pp. 612-626, 2008. 
[136] M. L. Choong, H. Yang, M. A. Lee, and D. P. Lane, "Specific activation of the p53 pathway by low dose actinomycin D: a new route to p53 based cyclotherapy," Cell Cycle, vol. 8, no. 17, pp. 2810-2818, 2009.

[137] H. M. Sobell, "Actinomycin and DNA transcription," Proceedings of the National Academy of Sciences of the United States of America, vol. 82, pp. 5328-5331, 1985.

[138] G. J. Veal, M. Cole, J. Errington et al., "Pharmacokinetics of dactinomycin in a pediatric patient population: a United Kingdom Children's Cancer Study Group study," Clinical Cancer Research, vol. 11, no. 16, pp. 5893-5899, 2005.

[139] J. T. Mondick, L. Gibiansky, M. R. Gastonguay et al., "Population pharmacokinetic investigation of actinomycin-D in children and young adults," Journal of Clinical Pharmacology, vol. 48, no. 1, pp. 35-42, 2008. 


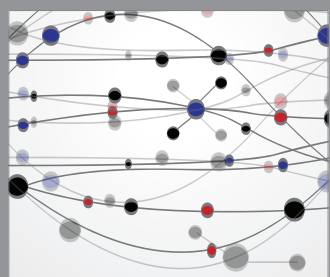

The Scientific World Journal
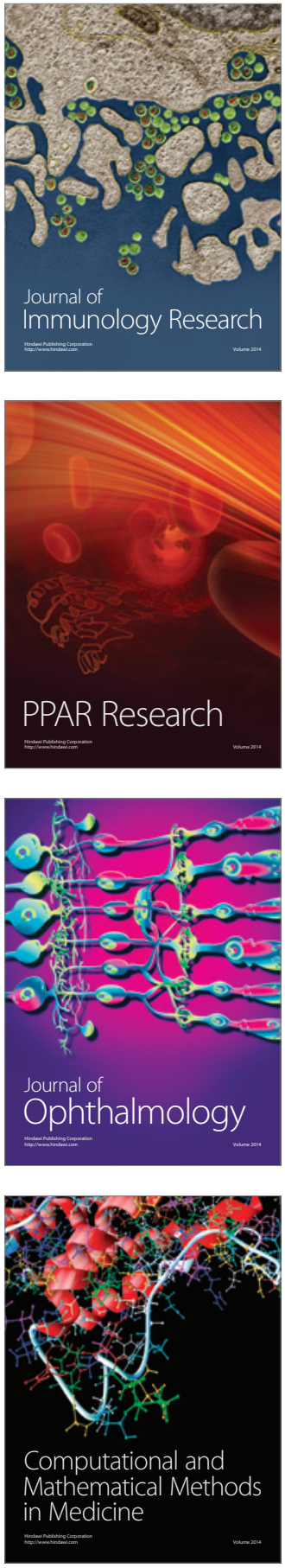

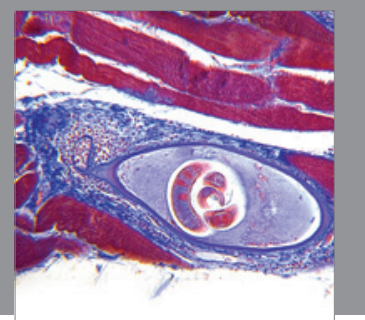

Gastroenterology

Research and Practice
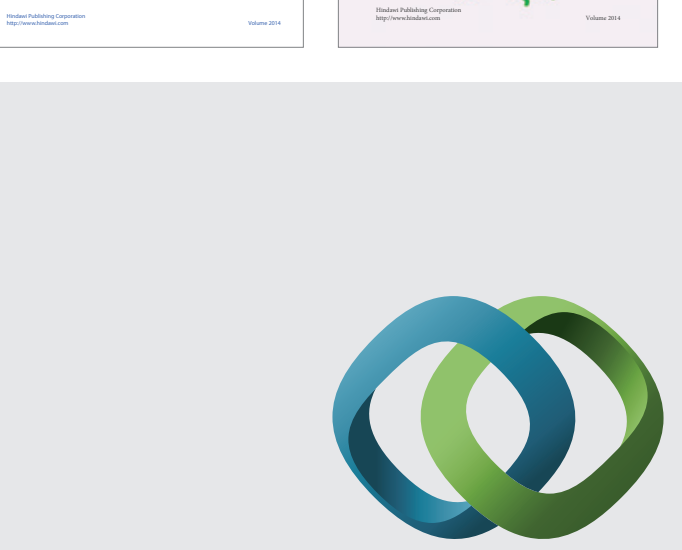

\section{Hindawi}

Submit your manuscripts at

http://www.hindawi.com
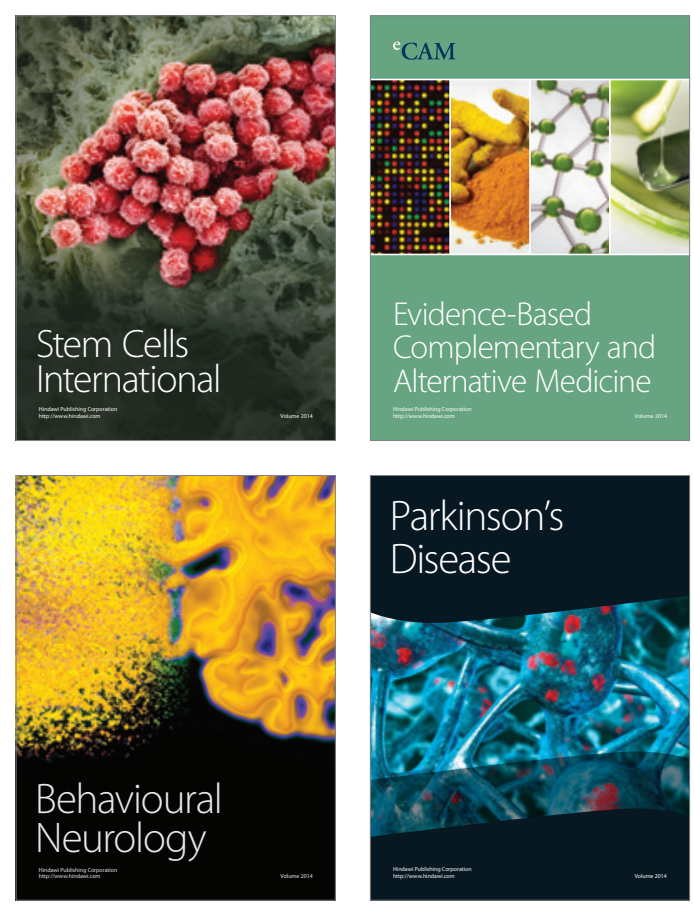

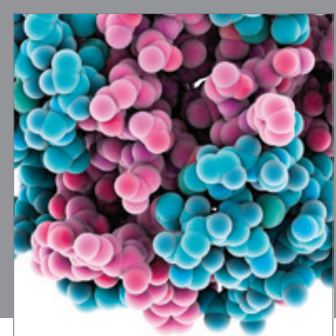

Journal of
Diabetes Research

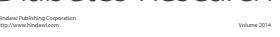

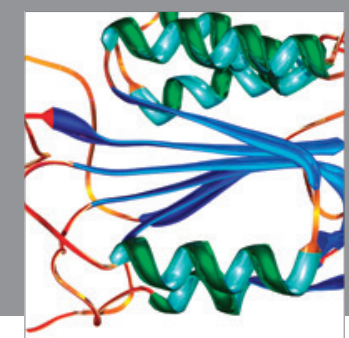

Disease Markers
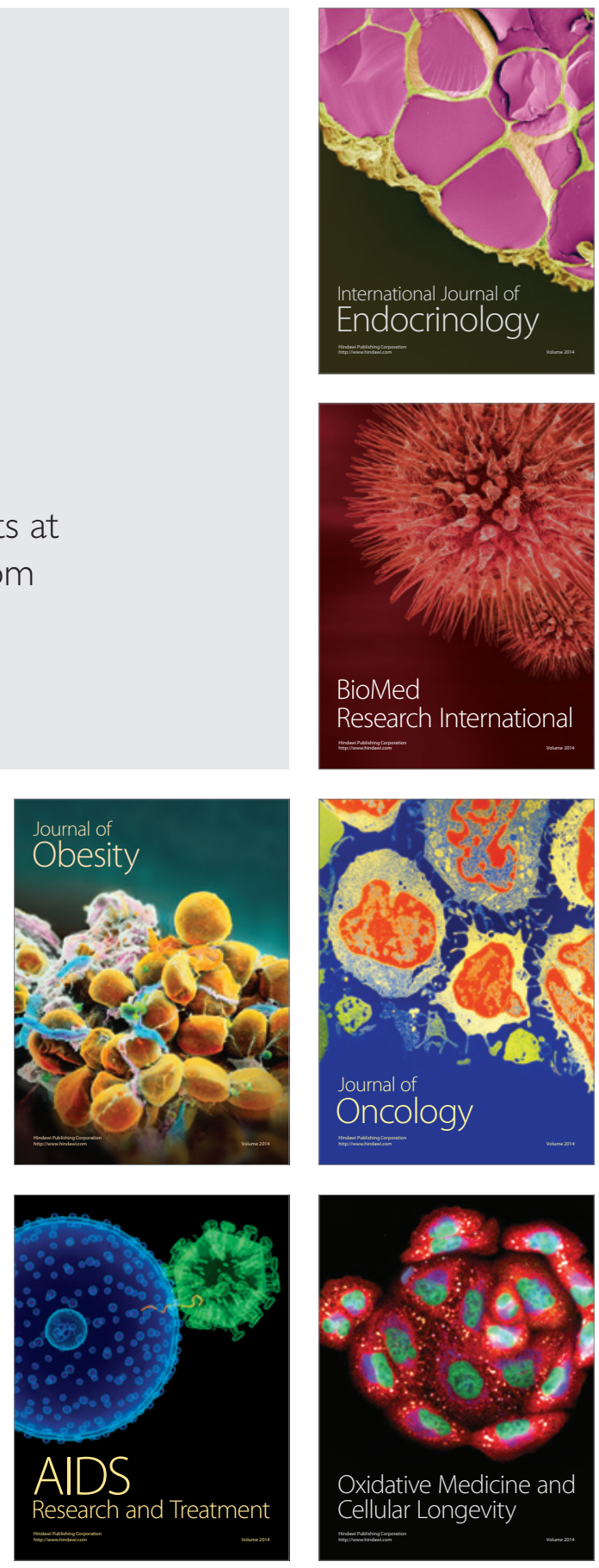